\title{
The Role of Wild Food Plants of Himachal Pradesh in Boosting Immunity to Combat COVID-19
}

\author{
Tara Devi Sen \\ Assistant Professor. Department of Botany, Sardar Vallabhbhai Patel, Cluster University, \\ Mandi, Himachal Pradesh, India.
}

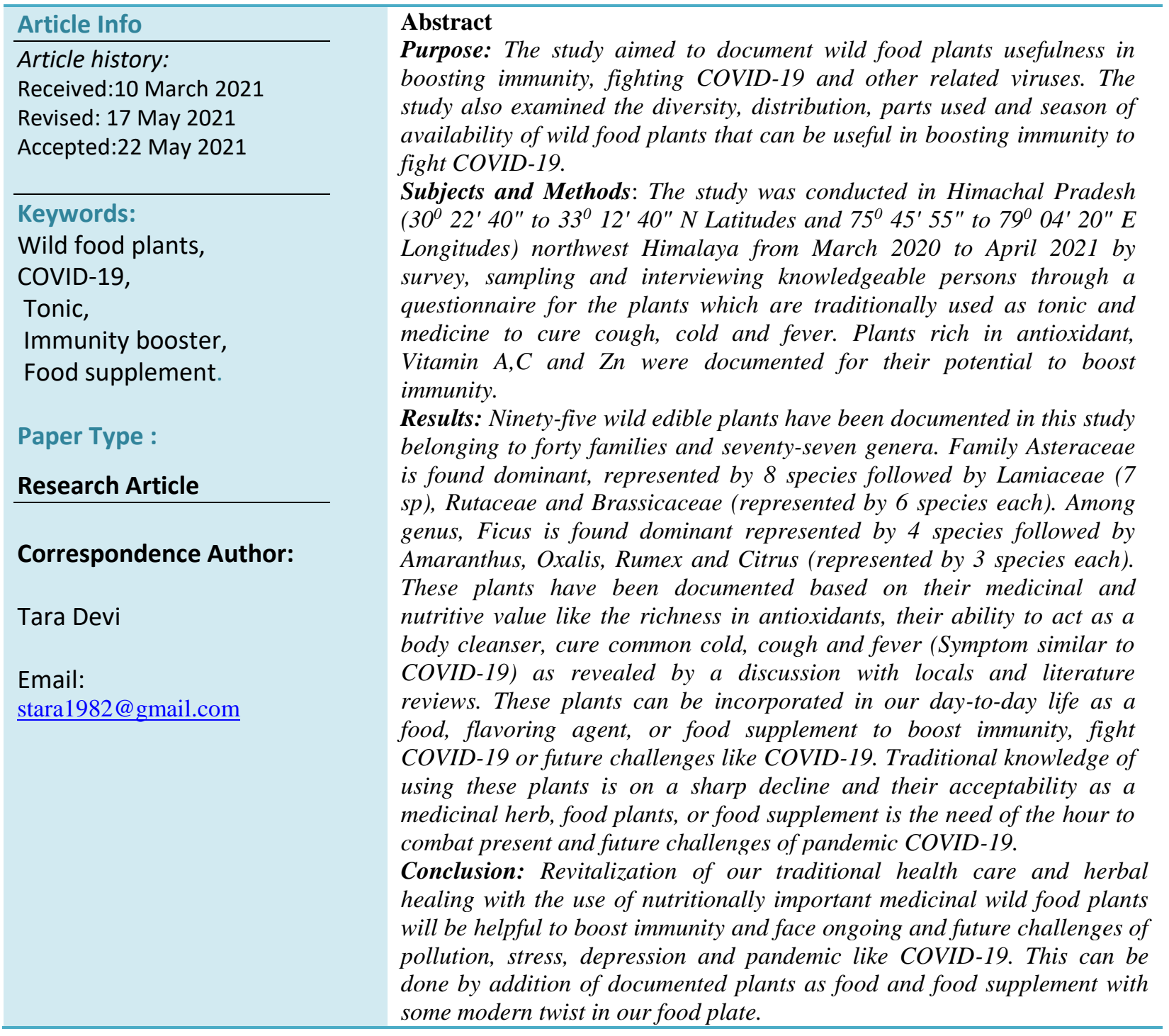

\section{Introduction}

Himalayan forests are the unique treasures of bio resources that act as an important source of medicinal and edible plants for the local communities (Bhat et al., 2013). People have been using these plants as food, fibers, oil, dyes, timbers, fuel, fodders, medicine and materials from time immemorial. Some of these plants also act as an important source of food at the time of scarcity and their use offers many advantages over commercial food plants. 
They give variety to our food plate and are a free source of nutrients for local people. They are relatively hardier, more resistant to diseases, insects and pests. Since they are free from harmful chemical fertilizers, insecticides and pesticides, they play an important role in boosting our immune system. In most cases, these are plants are multipurpose types, offering many other uses except food. People consume these food items as wild vegetables, wild fruits and food supplements in a variety of ways like raw, roasted, fried, cooked, boiled or in the form of oil, spice, seasoning material, jams, pickle, etc.

Local people have been eating food items prepared from these plants science ages but unfortunately, lost track somewhere at the dawn of modern times. The indigenous knowledge and practices of using these plants revolve around traditional practices and values of resource use that include subsistence, socio-cultural and economic-commercial values (Samant \& Dhar, 1997; Thakur, 2021).

Himachal Pradesh is endowed with rich floristic diversity and the population in this region is small due to hilly geography. Hence, people cannot afford optimum agricultural input and rely on a number of unconventional food plants like Achyranthes aspera, Cirsium arvense, Eclipta prostrata,Tinospora cordifolia,Centella asiatica, Euphorbia hirta, Taraxacum officinale and Urtica dioica, etc., for food, fiber, medicine and materials (Samant \& Dhar,1997; Devi T, 2020). Wild food plants like Euphorbia hirta, Moringa oleifera, Taraxacum officinale, Tinospora cordifolia Centella asiatica, and Urtica dioica are excellent immunity booster which can be employed as a food and food supplement in our day to day life. (Thakur, 2021) Himachal Pradesh is a well-known tourist destination during all seasons. Therefore, food preparation from these medicinal herbs can also be entered in the menu of different restaurants, hotels, private hotels, resorts, local restaurants \&Dhabas running across HP and adjoining states to boost immunity and avoid COVID-19 and other future challenges (Devi\&Sen, 2020).

Hence, the study aims to explore the indigenous knowledge, medicinal and nutritive value of wild food plants useful in boosting immunity, fight COVID-19 and future challenges like COVID-19. In addition, the study examines the traditional methods of involving these plants in our day-to-day life and latest methods of their use as a food and food supplement with modern twist.

\section{Methodology and Procedures}

The study is based on both primary and secondary data. Survey and sampling were done from June, 2020 to March, 2021. Rapid survey and sampling were done and information on wild food plants helpful in boosting immunity, their altitudinal range, habit, habitat (s), method of extraction, availability and utilization pattern was gathered by interviewing knowledgeable persons through a questionnaire. Identification of samples was done with the help of local and regional floras (Chowdhary \& Wadhwa, 1984: Collett, 1902, Dhaliwal\& Sharma, 1999; Singh, 1918). Plants rich in antioxidants, vitamin A \&C, minerals like Mg, Zn, and traditionally used as tonic and medicine to cure cough, cold and fever were documented for their potential to boost immunity, fight COVID-19 and future challenges like COVID-19. 


\section{Study Area:}

The study was conducted in Himachal Pradesh $\left(30^{\circ} 22^{\prime} 40^{\prime \prime}\right.$ to $33^{\circ} 12^{\prime} 40^{\prime \prime}$ N Latitudes and $75^{\circ} 45^{\prime} 55^{\prime \prime}$ to $79^{0} 04^{\prime} 20^{\prime \prime}$ E Longitudes) northwest Himalaya. The altitudinal Range of Himachal Pradesh is $350-6816 \mathrm{~m}$ and the temperature lies between $-13.8^{0} \mathrm{C}$ to $44.7^{0} \mathrm{C}$. It covers approximately55, $673 \mathrm{Km}^{2}$ areas, and comprises 3226 Panchayats, 20, 690 villages with 14, 83, 280 households and 6,864,602 human populations. The total livestock population is $11,04,476$. It supports diverse habitats, species, communities and Ecosystems. The vegetation mainly of sub-tropical and temperate types and mostly dominated by broad-leaved deciduous and evergreen and coniferous types. (District Economic and Statistical Department, Mandi, H.P).

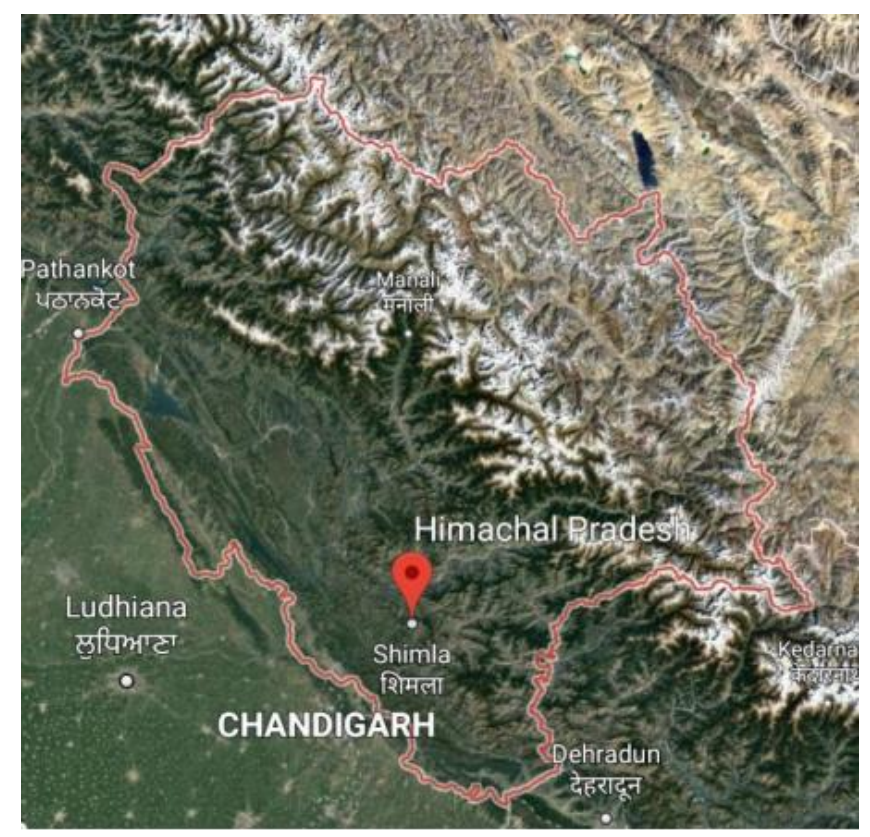

Fig. 1.Google Map of HP

Table 1: List of informants, members of SHG and buyers associated with nettle traditional use, processing and marketing

\begin{tabular}{|l|l|l|l|l|l|}
\hline $\begin{array}{l}\text { Sr. } \\
\text { No. }\end{array}$ & Name & Age & Gender & Address & Profession \\
\hline 1. & Yougraj Dogra & 28 & M & VII.- Ghat, PO- Ghat,Teh.-Balichowki, Distt.-Mandi. & Agriculture \\
\hline 2 & Sunitra Sen & 64 & F & Vil-Talyahar. PO-Talyahar-Teh-Sadar Distt.-Mandi. & $\begin{array}{l}\text { President of } 150 \\
\text { SHG }\end{array}$ \\
\hline 3. & Jaithi Devi & 72 & F & VII.- Ghat, PO- Ghat,Teh.-Balichowki, Distt.-Mandi. & Farming \\
\hline 4. & Bhop Singh & 70 & M & VILBaga, PO- Bagachanogi, Teh.-Thunag, Distt.-Mandi. & Agriculture \\
\hline 5. & $\begin{array}{l}\text { Rajender } \\
\text { prakash attri }\end{array}$ & 56 & M & VIL- Lashan, PO- Jabli, Teh.-Kasauli, Distt.-Solan. & Agriculture \\
\hline 6 & Poonam attri & 40 & F & VIL Lashan, PO-Jabli Teh.-Kasauli, Distt. Solan. & Agriculture \\
\hline 7. & Kalapati devi & 65 & M & VIL-Barot. PO- Chhat, Teh.- Gumarwin, Distt.-Bilaspur & Agriculture \\
\hline 8 & Shaddi devi & 70 & F & VIL-Balohni, PO- Bhekhli, Teh.-Kullu, Distt.-Kullu & Agriculture \\
\hline 9. & Naag Ram & 65 & M & VIL-Chubhani, PO- Bahyla, Teh-Thunag, Distt.-Mandi & Hakim, \\
\hline
\end{tabular}




\begin{tabular}{|c|c|c|c|c|c|}
\hline & & & & & Agriculture \\
\hline 10. & Parvati devi & 65 & $\mathrm{~F}$ & VIL- Baragaon, PO-Drang, Teh-Padha, Distt.-Mandi & Agriculture \\
\hline 11. & Sushil Kumari & 48 & $\mathrm{~F}$ & VIL Kalpa, PO- Kalpa,Teh.- Kalpa, Distt.-Kinnaur & Agriculture \\
\hline 12 & $\begin{array}{ll}\text { Vinay } & \text { singh } \\
\text { negi } & \end{array}$ & 43 & $\mathrm{M}$ & VIL Kalpa, PO- Kalpa, Teh.- Kalpa, Distt.-Kinnaur & Agriculture \\
\hline 19. & Parvati devi & 65 & $\mathrm{~F}$ & VIL-Baragaon PO. Drang Tehsil-Padhar Distt.Mandi & Agriculture \\
\hline 13. & Anup chand & 34 & $\mathrm{M}$ & $\begin{array}{l}\text { VIL- Baga. PO- Bagachanogi, } \\
\text { nagar,Distt.Mandi. }\end{array}$ & Agriculture \\
\hline 14. & Anupriya & 18 & $\mathrm{~F}$ & VIL= kotli, PO-Samraham, Teh- Kotli.Distt.-Mandi. & $\begin{array}{l}\text { Farming and } \\
\text { broom making }\end{array}$ \\
\hline 15. & Kehar singh & 62 & M & VIL-Chanju. PO -Chanju. Teh-Tissa,. Distt.-Chamba & Agriculture \\
\hline 16. & Rhekha Devi & 54 & $\mathrm{~F}$ & $\begin{array}{l}\text { Bard No-11Nagar Nigam Dharmshala, PO- Dharmshal. } \\
\text { Distt. -Dharamshala. }\end{array}$ & Farming \\
\hline 17 & Anita Kumari & 55 & $\mathrm{~F}$ & VIL-Panalth. PO Harsar. Teh Jawali,Distt. Kangra & Farming \\
\hline 18 & Meena Devi & 26 & $\mathrm{~F}$ & VIL.- Dari, PO- Chail chowk. Teh- chachyot,Distt -Mandi. & Agriculture \\
\hline 19 & Jagdish Thakur & 52 & M & VIL-Chanala. PO- Kamand, Teh- Sadar. Distt -Mandi. & Perist, Farming \\
\hline 20 & $\begin{array}{l}\text { Dr. Monica } \\
\text { Sharma }\end{array}$ & 38 & $\mathrm{~F}$ & $\begin{array}{l}\text { Dr. YS Parmar, University Of Horticulture \& Forestry } \\
\text { (Solan) Neri. Hamirpur }\end{array}$ & $\begin{array}{l}\text { Associate } \\
\text { Professor }\end{array}$ \\
\hline 21. & Khimi Devi & 45 & $\mathrm{~F}$ & $\begin{array}{l}\text { Vill- Patyoda, P.O.- Maloh, Teh--SundenagarDistt - } \\
\text { Mandi. }\end{array}$ & $\begin{array}{l}\text { Agriculture, } \\
\text { Pickle making }\end{array}$ \\
\hline 22. & Lata devi & 43 & $\mathrm{~F}$ & Village-Kamand, P.O. Kamand, Tehsil Sadar Mandi. & $\begin{array}{l}\text { Pickle and } \\
\text { Badiyan selling }\end{array}$ \\
\hline 23. & Jaya Devi & 37 & $\mathrm{~F}$ & Vill.- Jadron, P.O.- Bayla, Teh-Sundenagar.Distt -Mandi. & $\begin{array}{l}\text { Traditional } \\
\text { Processing of } \\
\text { Herbs }\end{array}$ \\
\hline 24. & Sarla Devi & 40 & $\mathrm{~F}$ & Vill.- Jadron, P.O.- Bayla, Teh-Sundenagar.Distt -Mandi. & $\begin{array}{l}\text { SHG member } \\
\text { herb selling }\end{array}$ \\
\hline 25 & $\begin{array}{ll}\text { Mr. } & \text { Jaswant } \\
\text { Singh } & \end{array}$ & 43 & $\mathrm{M}$ & $\begin{array}{l}\text { Village Luhnu, P.O. Bayla Tehsil- SundernagarDistt - } \\
\text { Mandi. }\end{array}$ & Panchyat Pardhan \\
\hline
\end{tabular}

\section{Results and Discussion}

1.To know diversity, distribution, parts used and season of availability of wild food plants usefullness in boosting immunity, fighting COVID-19 and for future challenges like COVID-19.

Ninety-five(T= $12 \mathrm{spp} ; \mathrm{Sh}=21 \mathrm{spp} . \mathrm{H}=59 \mathrm{spp}$. Fruiting Body=3) plant species belonging to forty families and seventy seven genera were documented. These are known to have rich nutritive, medicinal value and are excellent sources of minerals like $\mathrm{Zn}, \mathrm{Mg}$ and antioxidants like Vitamin A, C, D, etc. Family Asteraceae has been found dominant represented by 8 species followed by Lamiaceae $(7$ sp.) Rutaceae and Brassicaceae (represented by $6 \mathrm{sp}$. each). Among genus, Ficus was found dominant represented by 4 sp. followed by Amaranthus, Oxalis,Rumex and Citrus represented by $3 \mathrm{sp}$. each. Most of these wild plants are used by local people to get rid of cough, cold, bronchitis and can be further employed to boost immunity and protection from COVID -19 Table 2. Fig 1,2. 


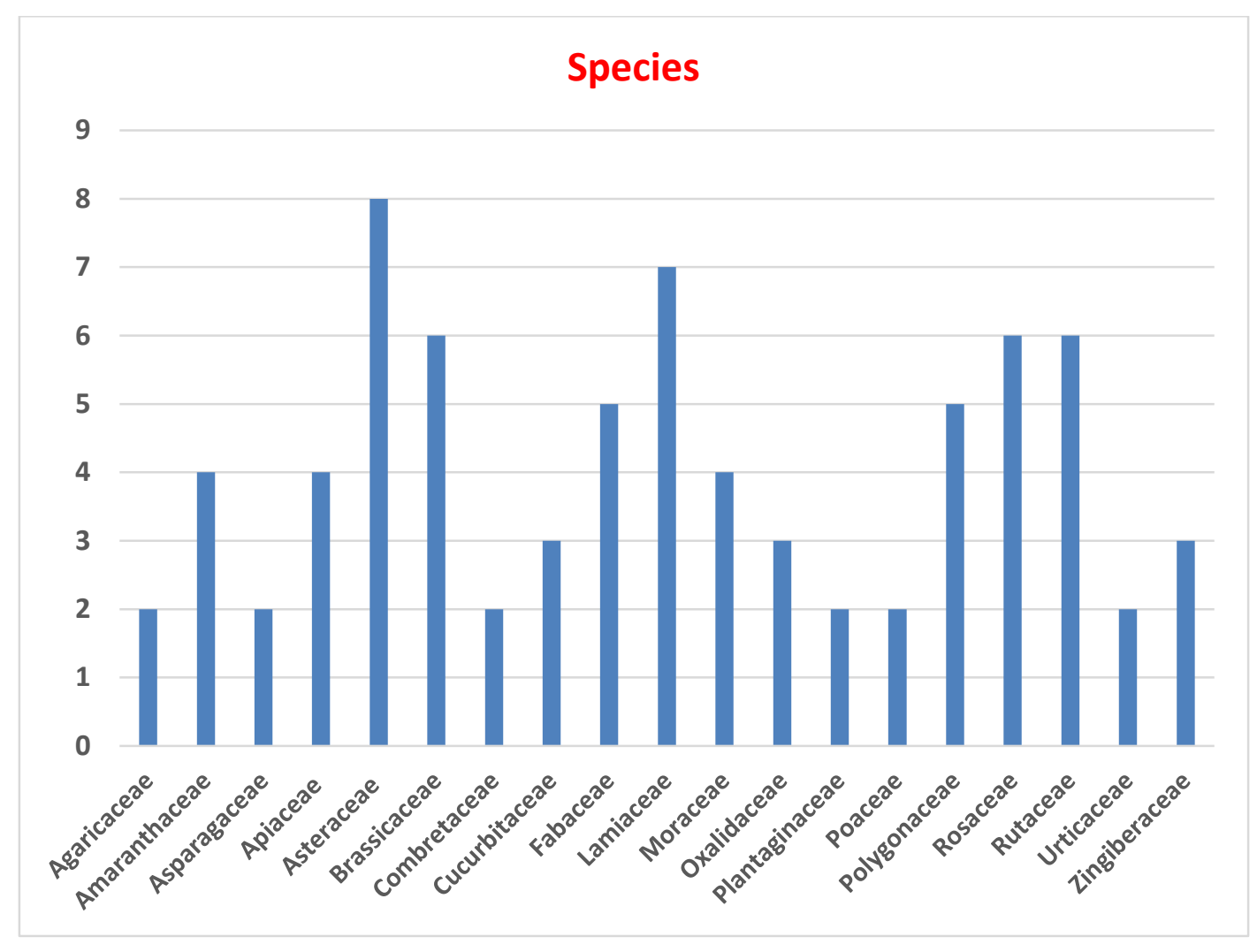

Fig. 2.Diversity of dominant families having wild food plants helpful to prevent COVID-19

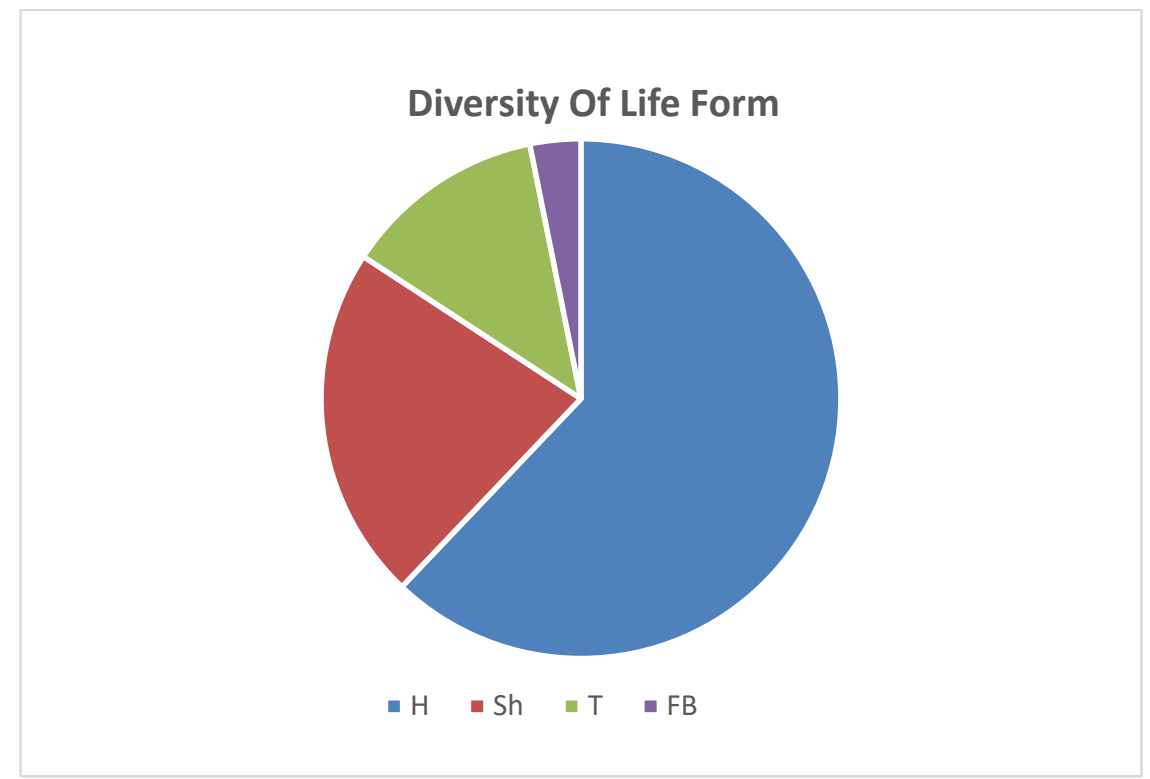

Fig. 3.Diversity of life form of wild food plants helpful to prevent COVID-19

Table 2: Diversity, Distribution, parts used, food value, Indigenous knowledge, food value, medicinal value $\&$ season of availability of wild food plants useful in boosting immunity and fight COVID-19

\begin{tabular}{|l|l|l|l|l|l|l|}
\hline $\begin{array}{l}\text { Family/ } \\
\text { Botanical } \\
\text { Name/common } \\
\text { Name/ Local } \\
\text { name }\end{array}$ & $\begin{array}{l}\text { Cuisin } \\
\text { e }\end{array}$ & $\begin{array}{l}\text { Parts } \\
\text { Used }\end{array}$ & $\begin{array}{l}\text { Altitudinal } \\
\text { Range (m) } \\
\text { \& Habit }\end{array}$ & Food Value (Fd) & \multicolumn{2}{|l|}{$\begin{array}{l}\text { Availability } \\
\text { Market } \\
\text { rate (Rs) }\end{array}$} \\
\cline { 5 - 7 } & & & & Local Uses & Uses in Literature \\
\hline
\end{tabular}




\begin{tabular}{|c|c|c|c|c|c|c|c|}
\hline $\begin{array}{l}\text { Macrolepiota } \\
\text { proceral Parasol } \\
\text { mushroom / } \\
\text { Badi chhattri }\end{array}$ & $\begin{array}{l}\text { Veget } \\
\text { able, } \\
\text { Pickle. } \\
\text { Palau/ }\end{array}$ & $\begin{array}{l}\text { Fruitin } \\
\text { g body }\end{array}$ & $\begin{array}{l}\text { Fruiting } \\
\text { body }\end{array}$ & 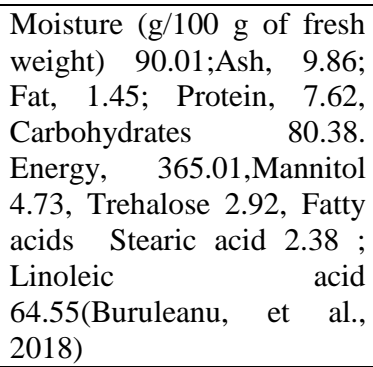 & & $\begin{array}{lr}\text { Possess } & \text { antioxidant, } \\
\text { antimicrobial, } & \text { and } \\
\text { anticancer } & \\
\text { properties(Fernandes,et al., } \\
2018 \text { ) }\end{array}$ & $\begin{array}{l}\text { Rainy } \\
\text { season to } \\
\text { early } \\
\text { autumn/ }\end{array}$ \\
\hline \multicolumn{8}{|l|}{ Alliaceae } \\
\hline $\begin{array}{l}\text { Allium } \\
\text { ampeloprasum/ } \\
\text { Wild Leek } \\
\text { Elephant Garlic/ } \\
\text { Luhan }\end{array}$ & $\begin{array}{l}\text { Veg, } \\
\text { siddu, } \\
\text { Chutn } \\
\text { ey }\end{array}$ & $\begin{array}{l}\text { Bu, } \\
\text { Lf, \& } \\
\text { Fl }\end{array}$ & $\begin{array}{l}1500-3000 \\
\mathrm{~m}(\mathrm{H})\end{array}$ & $\begin{array}{l}100 \mathrm{~g} \text { of cloves contain } \\
\text { Water } 78.3 \mathrm{~g} \text {, Energy } 85 \\
\text { Kcal, Protein } 1.67 \mathrm{~g} \text {, Total } \\
\text { Fat (lipid) } 0.34 \mathrm{~g} \text {, Ash } 0.79 \\
\text { g, Carbohydrate } 16.6 \mathrm{~g} \text {, } \\
\text { Total dietary Fiber } 4.23 \mathrm{~g} \text {, } \\
\mathrm{Ca} 75.6 \mathrm{mg}, \mathrm{Fe}, 0.54 \mathrm{mg} \text {, } \\
\mathrm{Mg}, 17.1 \mathrm{mg}, \mathrm{K} 455 \mathrm{mg} \text {, } \\
\mathrm{Na}, 32.7 \mathrm{mg}, \mathrm{Zn}, 0.752 \mathrm{mg} \text {, } \\
\mathrm{Cu}, 0.11 \mathrm{mg}, \mathrm{Mn} 0.11 \mathrm{mg} \text {, } \\
\text { Vit. B9, } 145 \mu \mathrm{g} ; \text { Vit. C, } \\
3.44 \mathrm{mg} ; \text { Vit. E, } 0.03 \mathrm{mg} \text {, } \\
\text { Oxalic acid 50.3 mg, } \\
\text { Glutamic acid } 21.7 \mathrm{mg} \text {, } \\
\text { Malic acid 70.9 mg, Citric } \\
\text { acid } 24.4 \mathrm{mg}, \text { Fumaric acid } \\
\text { 0.85 mg, Succinic acid } 2.14 \\
\text { mg } \\
\text { https://www.nutritionvalue. } \\
\text { org/Mushrooms\%2C_raw\% } \\
\text { 2C_morel_nutritional_value } \\
\text {.html }\end{array}$ & $\begin{array}{l}\text { Used to } \\
\text { manage } \\
\text { highcholester } \\
\text { ol. }\end{array}$ & $\begin{array}{l}\text { Boost oxygen distribution } \\
\text { in the body, increases } \\
\text { energy levels, and supports } \\
\text { healthy immune function } \\
\text { (Bown, 1995) }\end{array}$ & $\begin{array}{l}\text { Late autumn } \\
\text { to the rainy } \\
\text { season/ }\end{array}$ \\
\hline Amaranthaceae & & & & & & & \\
\hline
\end{tabular}




\begin{tabular}{|c|c|c|c|c|c|c|c|}
\hline $\begin{array}{l}\text { Achyranthes } \\
\text { aspera/ Devil's } \\
\text { Horsewhip/ } \\
\text { Puthkanda }\end{array}$ & $\begin{array}{l}\text { Kheer, } \\
\text { Veg, } \\
\text { Kachr } \\
\text { u, }\end{array}$ & Lf, Sd & $\begin{array}{ll}2000 & \mathrm{~m} \\
(\mathrm{Sh}) & \end{array}$ & $\begin{array}{l}\text { Plant contains moisture } \\
4.05 \% \text {, proteins } 20.54 \% \text {, } \\
\text { fats } 0.903 \% \text {, ash } 20.25 \%, \\
\text { carbohydrates } 54,26 \% \text { and } \\
\text { energy } 294 \mathrm{Kcal} \text {. Vitamin } \\
\text { profile was found to be } \mathrm{B}(1) \\
0.27 \mathrm{mg} / 100 \mathrm{~g}, \mathrm{~B}(2) \\
0.28 \mathrm{mg} / 100 \mathrm{~g}, \mathrm{~B}(3) \\
0.58 \mathrm{mg} / 100 \mathrm{~g}, \mathrm{~B}(6) \\
0.27 \mathrm{mg} / 100 \mathrm{~g} \text { and } \mathrm{B}(9) \\
39 \mu \mathrm{g} / 100 \mathrm{~g} . \text { The content of } \\
\mathrm{Na}, \mathrm{Ca}, \mathrm{Mg}, \mathrm{K}, \mathrm{Cl} \text { and } \mathrm{P} \\
\text { was found to be } 1119.67, \\
5385.23,5446.08,1343.6, \\
675880.73 \text { and } \\
1447.5 \mathrm{mg} / \mathrm{kg} \text { respectively } \\
\text { and trace metals i.e. Fe, Cu, } \\
\mathrm{Zn}, \mathrm{Mn} \text { and } \mathrm{Al} \text { were } \\
\text { detected as } 283.05,8.062, \\
48.37,16.12 \text { and } 9.853 \\
\text { mg/kg } \\
\text { respectively.https://www.nc } \\
\text { bi.nlm.nih.gov/pubmed/251 } \\
76360 .\end{array}$ & $\begin{array}{l}\text { The whole } \\
\text { plant is useful } \\
\text { in the } \\
\text { treatment of } \\
\text { dropsy, piles, } \\
\text { boils, } \\
\text { toothache and } \\
\text { skin } \\
\text { problems. Rt } \\
\& \text { St are } \\
\text { useful in } \\
\text { toothache \& } \\
\text { used as a } \\
\text { toothbrush. }\end{array}$ & $\begin{array}{l}\text { Used as diuretic, febrifuge, } \\
\text { abortifacient, germicidal, } \\
\text { tonic and pot- herb and for } \\
\text { asthma, antifertility in } \\
\text { women, boils, bronchitis, } \\
\text { cold, colic, child birth, } \\
\text { cough, debility, dropsy, } \\
\text { dysentery, ear complaints, } \\
\text { eye complaints, headache, } \\
\text { hydrophobia, insect- bite, } \\
\text { liver complaints, pain in } \\
\text { ribs and body, piles, } \\
\text { pneumonia, reducing } \\
\text { hunger, renal complaints } \\
\text { rheumatism, scabies, } \\
\text { scorpion- bite, skin } \\
\text { diseases, snake- bite, sore, } \\
\text { stomachache, syphilis, } \\
\text { toothache whooping cough, } \\
\text { wounds; and also to expel } \\
\text { placenta, worms and ward } \\
\text { off ghosts. It is reported to } \\
\text { be useful in cancer. } \\
\text { (Karnick et al., 1981.Jain, } \\
\text { 1991;Purohit, et, al,. 2009) }\end{array}$ & $\begin{array}{l}\text { Spring } \\
\text { season to } \\
\text { pre-winter/ }\end{array}$ \\
\hline $\begin{array}{l}\text { Amaranthus } \\
\text { tricolor } \\
\text { /Chinese } \\
\text { Spinach/ } \\
\text { Chaulai }\end{array}$ & $\begin{array}{l}\text { Saag, } \\
\text { Upmm } \\
\text { a, } \\
\text { Rehdo } \\
\text { o, } \\
\text { Kheer }\end{array}$ & $\begin{array}{l}\text { Ts, Lf } \\
\& \text { Sd }\end{array}$ & $2000 \mathrm{~m}(\mathrm{H})$ & $\begin{array}{l}\text { Lf contain about } 3.5 \% \\
\text { protein, } 0.25 \% \text { fat, } 6.6 \% \\
\text { carbohydrate, } 3.1 \% \text { ash, } \\
24 \mathrm{mg} \text { Fe per } 100 \mathrm{~g}, 464 \mathrm{mg} \\
\text { Ca per } 100 \mathrm{~g}, \text { they are rich } \\
\text { in vitamin A \& have a fair } \\
\text { content of vitamins B1 \& C. } \\
\text { On a zero-moisture basis } \\
100 \mathrm{~g} \text { of the Lf contains up } \\
\text { to } 2441 \mathrm{mg} \mathrm{Ca}, 1008 \mathrm{mg} \text { P, } \\
51 \mathrm{mg} \mathrm{Fe,} \mathrm{34mg} \mathrm{Na,} \\
4475 \mathrm{mg} \mathrm{K}, 37,623 \mathrm{mg} \text { beta- } \\
\text { carotene equivalent, } 0.68 \mathrm{mg} \\
\text { B1, 2.37mg B2, } 11.48 \mathrm{mg} \\
\text { B3\& 730mg C(Purohit et } \\
\text { al., 2009) }\end{array}$ & $\begin{array}{l}\text { Decoction of } \\
\text { mature plant } \\
\text { is helpful to } \\
\text { strengthen } \\
\text { liver and eve } \\
\text { sight. }\end{array}$ & $\begin{array}{l}\text { The plant is considered to } \\
\text { be astringent, diuretic, } \\
\text { appetizing, digestive \& } \\
\text { leucorrhoea (Duke and } \\
\text { Ayensu, 1985) }\end{array}$ & $\begin{array}{l}\text { Pre-summer } \\
\text { to the rainy } \\
\text { season } \\
\mathrm{Sd}=\text { summer } \\
\text { to the } \\
\text { beginning of } \\
\text { autumn }\end{array}$ \\
\hline $\begin{array}{l}\text { Amaranthus viri } \\
\text { dis/Wild } \\
\text { amaranth/Chaul } \\
\text { ayee }\end{array}$ & $\begin{array}{l}\text { Saag, } \\
\text { Upmm } \\
\text { a,Rehd } \\
\text { oo,Kh } \\
\text { eer }\end{array}$ & $\begin{array}{l}\text { Ts, Lf, } \\
\text { and St }\end{array}$ & (H) & $\begin{array}{l}100 \mathrm{~g} \text { fresh Lf contains } \\
87.9 \text { per cent moisture; } 2.11 \\
\mathrm{~g} \text { crude protein, } 1.93 \mathrm{~g} \\
\text { crude fibre, } 7.76 \mathrm{~g} \\
\text { carbohydrates, } 0.47 \mathrm{~g} ; \text { fat } \\
\text { and } 1.85 \mathrm{~g} \text { of total minerals. } \\
\text { The calorific value has been } \\
\text { found to be } 43.35 \mathrm{kcal} \text {. } \\
\text { (Anonymous, } 1985 \text { ) }\end{array}$ & $\begin{array}{l}\text { Considered } \\
\text { good to cure } \\
\text { excess } \\
\text { bleeding } \\
\text { during } \\
\text { menstruation } \\
\text { fever, cough } \\
\text { and strengthen } \\
\text { liver, eye } \\
\text { sight. }\end{array}$ & $\begin{array}{l}\text { Fresh Lf or dried powder, } \\
\text { are used in poultices to treat } \\
\text { inflammations, boils and } \\
\text { abscesses, } \\
\text { gonorrhoea,bronchitic and } \\
\text { haemorrhoids.(Kirtikar } \\
\text { \&Basu, 1935) }\end{array}$ & $\begin{array}{l}\text { Bunches of } \\
250-300 \quad \mathrm{~g} \\
\text { of chulayee } \\
\text { easily sell } \\
\text { for } 10-15 \\
\text { rupees. }\end{array}$ \\
\hline & & & & & & & \\
\hline
\end{tabular}




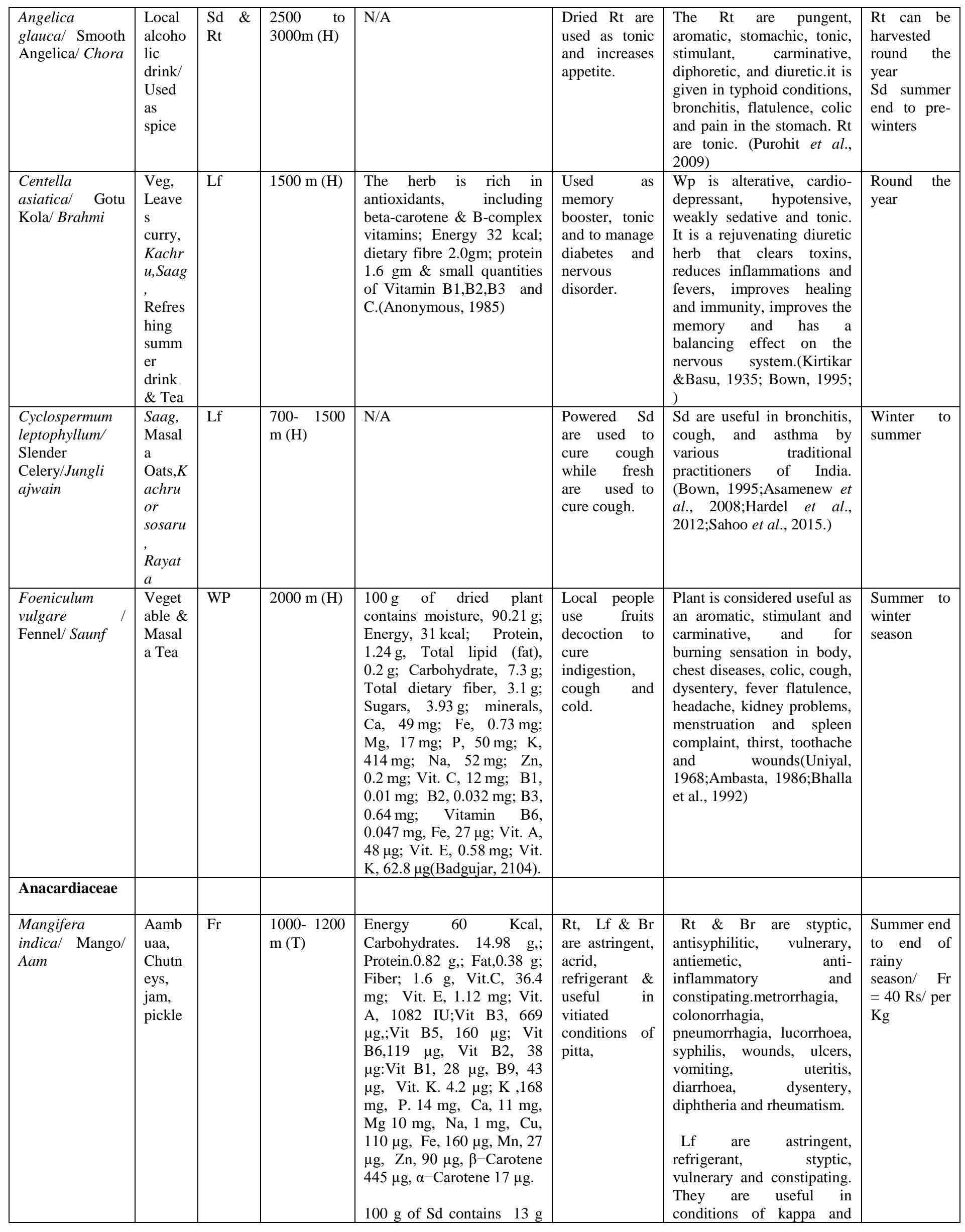




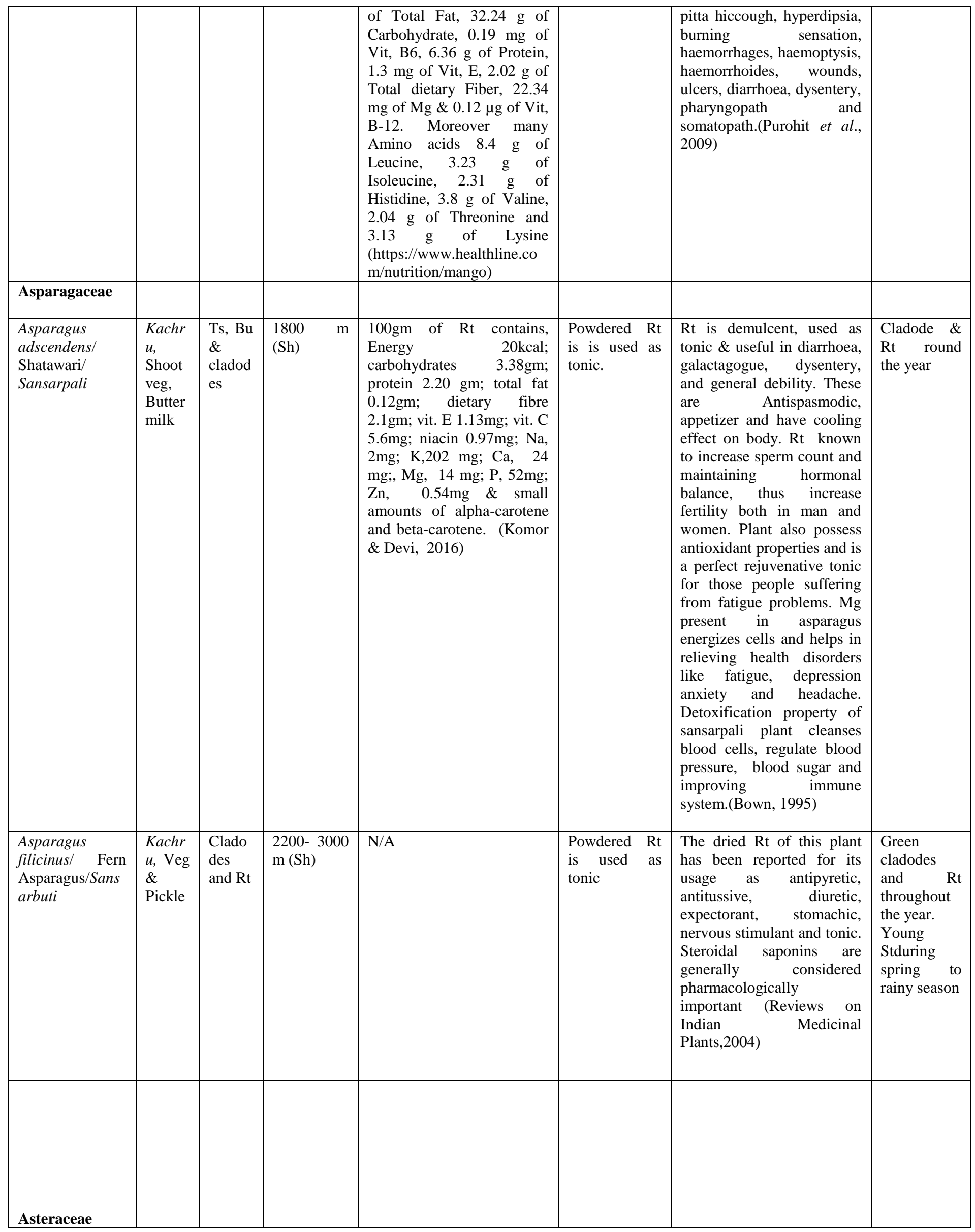




\begin{tabular}{|c|c|c|c|c|c|c|c|}
\hline $\begin{array}{l}\text { Achillea } \\
\text { millefolium / } \\
\text { Yarrow/ Losar }\end{array}$ & $\begin{array}{l}\text { Saag, } \\
\text { Herbal } \\
\text { Tea } \\
\& K a c \\
h r u\end{array}$ & $\begin{array}{ll}\text { Lf } & \& \\
\text { Fl } & \end{array}$ & $\begin{array}{l}1800-3500 \\
\mathrm{~m}(\mathrm{H})\end{array}$ & N/A & $\begin{array}{l}\text { Local people } \\
\text { chew the Lf or } \\
\text { Rt to relieves } \\
\text { toothache for } \\
\text { immediate } \\
\text { effect. } \\
\text { homoeopathic } \\
\text { medicines as a } \\
\text { carminative, } \\
\text { tonic, } \\
\text { stimulant and } \\
\text { diuretic }\end{array}$ & $\begin{array}{l}\text { A decoction of the Lf \& Fl } \\
\text { heads is employed as a } \\
\text { carminative, tonic and } \\
\text { aromatic stimulant } 8.9 \text {. It } \\
\text { expels kidney stones and is } \\
\text { useful in fever, nasal } \\
\text { congestion and stomach } \\
\text { diseases. (Purohit et al., } \\
\text { 2009; Singh, 2018) }\end{array}$ & $\begin{array}{l}\text { Summer to } \\
\text { rainy season }\end{array}$ \\
\hline $\begin{array}{l}\text { Cirsium } \\
\text { arvensel } \\
\text { Creeping } \\
\text { Thistle/ Chiuli }\end{array}$ & $\begin{array}{l}\text { Veg, } \\
\text { Saag }\end{array}$ & $\begin{array}{l}\text { St, Lf } \\
\& \mathrm{Rt}\end{array}$ & $1500 \mathrm{~m}(\mathrm{H})$ & N/A & $\begin{array}{l}\text { Rt is tonic, } \\
\text { diuretic, Rt } \\
\text { juice has } \\
\text { cooling effect } \\
\text { on body and } \\
\text { very effective } \\
\text { remedy } \\
\text { against nose } \\
\text { bleeding, }\end{array}$ & $\begin{array}{l}\text { Rt is often chewed as a } \\
\text { remedy for toothache. Rt } \\
\text { astringent, antiphlogistic } \\
\text { and hepatic..poultice is used } \\
\text { to } \\
\text { headache((Kirtikar \&Basu, } \\
\text { 1935) }\end{array}$ & $\begin{array}{l}\text { St, Lf \& Rt } \\
\text { throughout } \\
\text { the year }\end{array}$ \\
\hline $\begin{array}{l}\text { Erigeron } \\
\text { annuus/ Annual } \\
\text { Fleabane/ } \\
\text { Phuntha }\end{array}$ & $\begin{array}{l}\text { Saag\& } \\
\text { Tea }\end{array}$ & $\mathrm{Lf}$ & $1800 \mathrm{~m}(\mathrm{H})$ & N/A & $\begin{array}{l}\text { Tea is made to } \\
\text { get relief } \\
\text { from cough. }\end{array}$ & 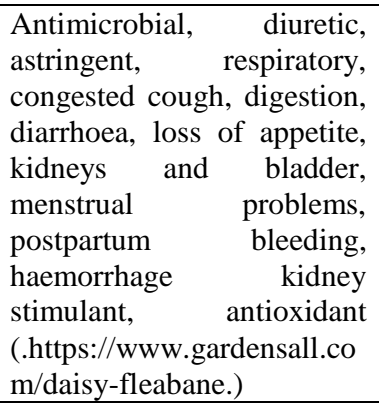 & $\begin{array}{l}\text { Summer to } \\
\text { autumn/ }\end{array}$ \\
\hline $\begin{array}{l}\text { Gamochaeta } \\
\text { pensylvanica/ } \\
\text { Spoonleaf } \\
\text { purple } \\
\text { everlasting/ } \\
\text { Dhoodu }\end{array}$ & $\begin{array}{l}\text { Saag, } \\
\text { Kachr } \\
u,\end{array}$ & Ap & $1700 \mathrm{~m}(\mathrm{H})$ & N/A & $\begin{array}{l}\text { Used as a } \\
\text { gargle or rinse } \\
\text { to treat mouth } \\
\text { or throat } \\
\text { diseases }\end{array}$ & $\begin{array}{l}\text { Used to cure diabetes, high } \\
\text { blood pressure, stomach } \\
\text { ulcers, diarrhea, gut } \\
\text { infections etc. (Chopra et } \\
\text { al.,1982) }\end{array}$ & $\begin{array}{l}\text { Spring to } \\
\text { pre- winter } \\
\text { season }\end{array}$ \\
\hline $\begin{array}{lr}\text { Sonchus } & \text { asper/ } \\
\text { Blue } & \text { sow- } \\
\text { thistle/ } & \\
\text { Bhursalae } & \end{array}$ & $\begin{array}{l}\text { Veg, } \\
\text { Saag\& } \\
\text { Soup }\end{array}$ & Ts & $4000 \mathrm{~m}(\mathrm{H})$ & N/A & $\begin{array}{lc}\text { Powdered } & \text { Ap } \\
\text { parts } & \text { are } \\
\text { excellent } & \\
\text { remedy } & \text { for } \\
\text { headache } & \&\end{array}$ & $\begin{array}{l}\text { Plant extract is applied to } \\
\text { fresh injuries \& latex in the } \\
\text { plant has been used as a } \\
\text { treatment on warts. sore } \\
\text { throat, Consuming a few Lf }\end{array}$ & $\begin{array}{lr}\text { leaves } & \text { from } \\
\text { spring } & \text { to } \\
\text { autumn } & \end{array}$ \\
\hline
\end{tabular}




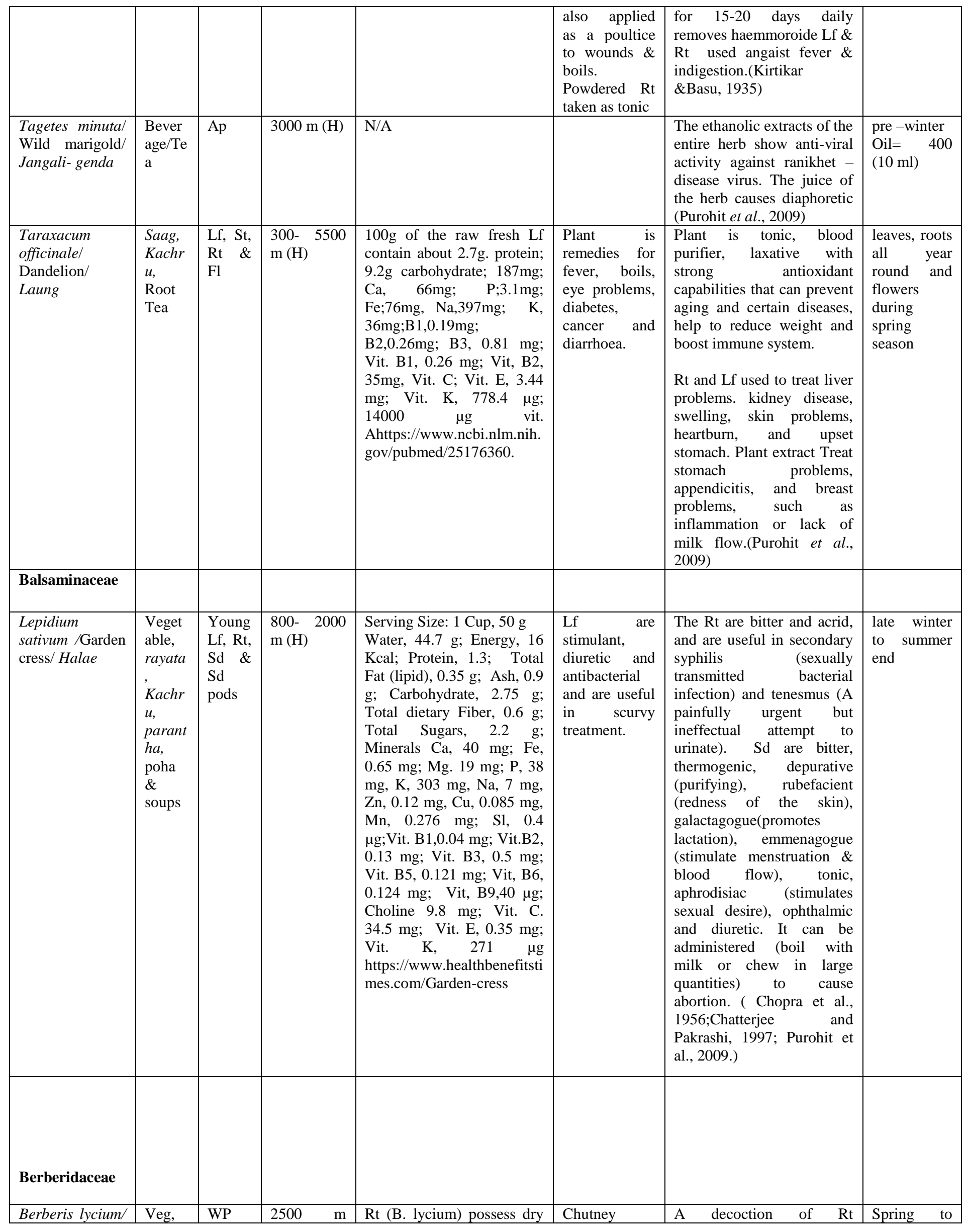




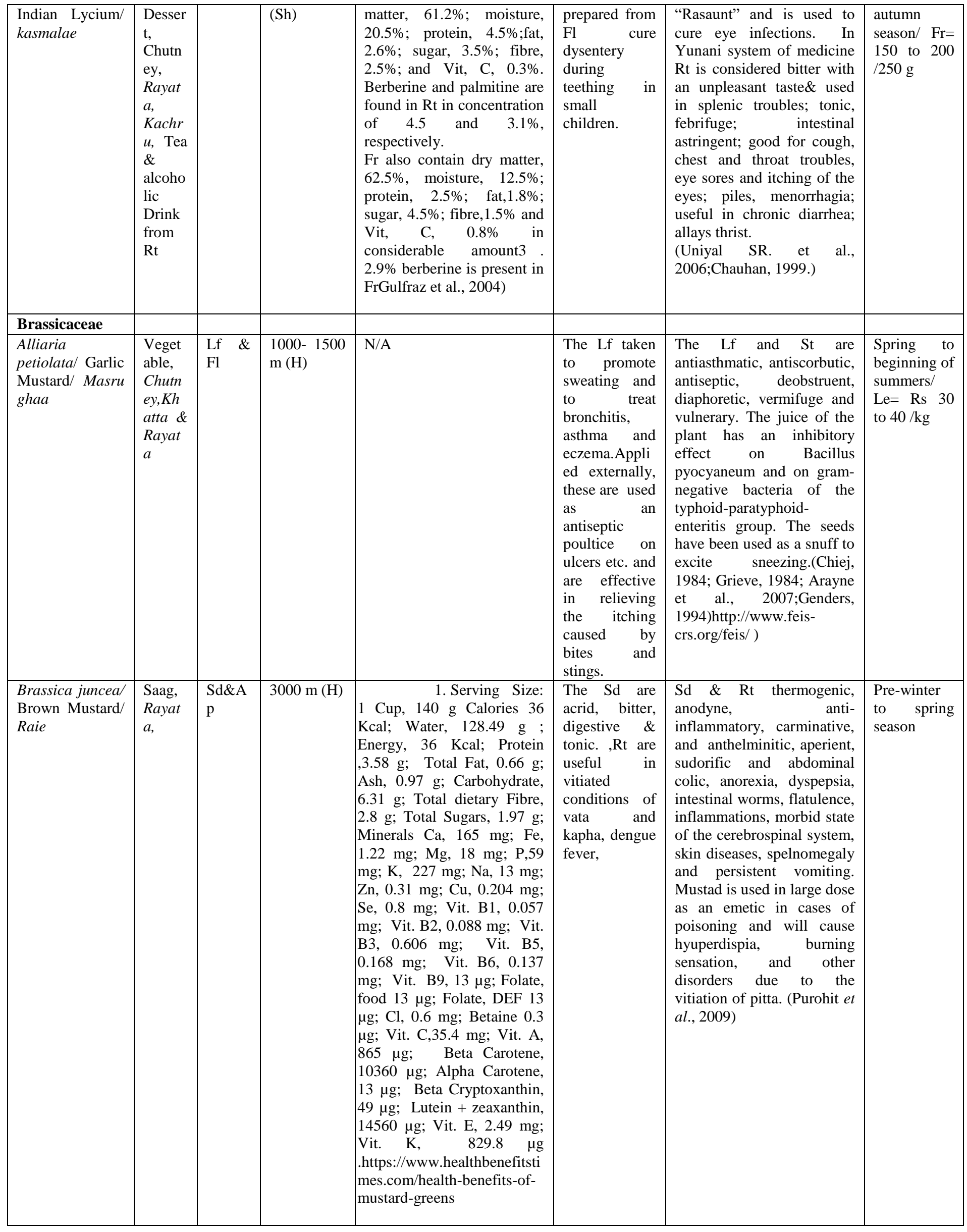




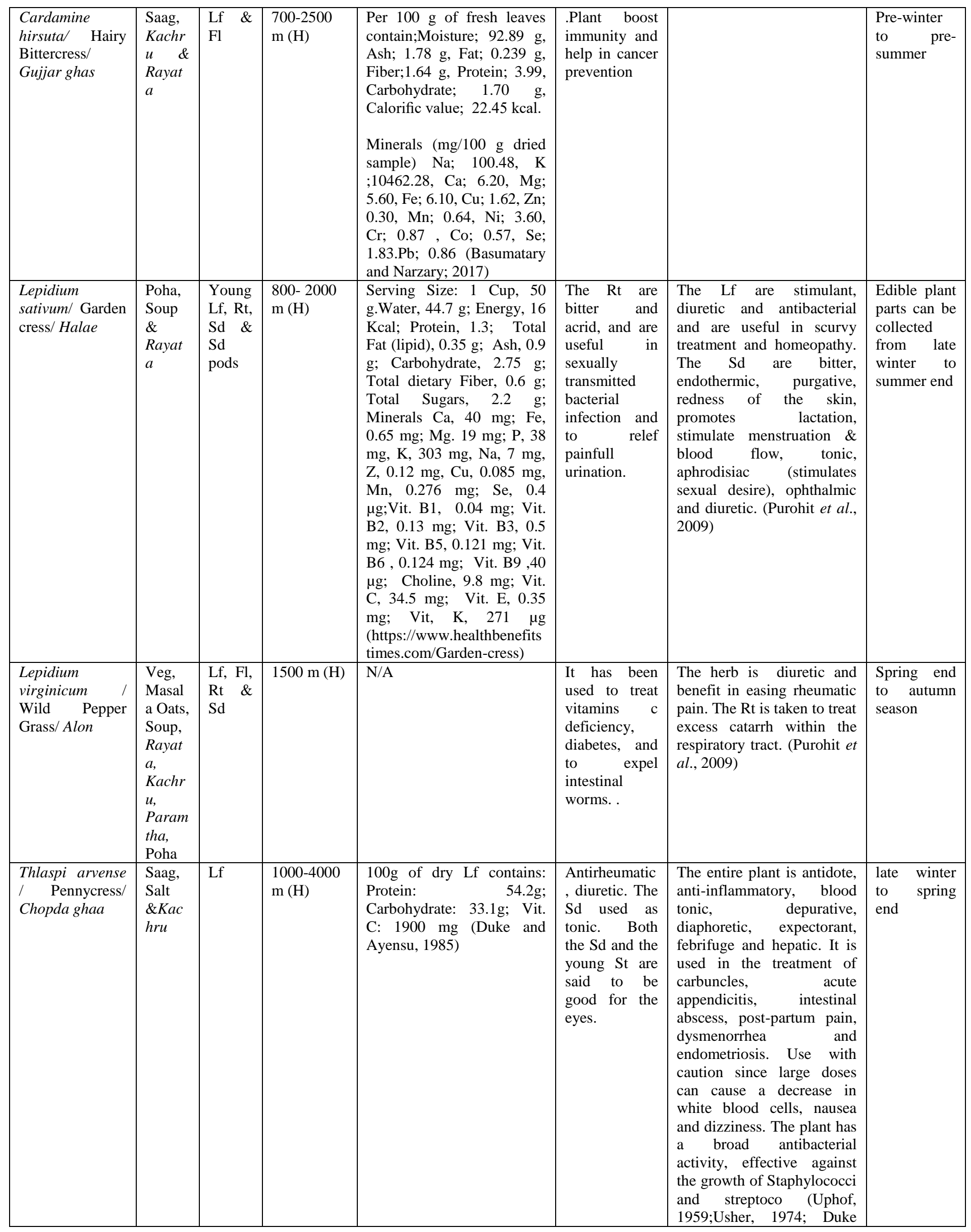




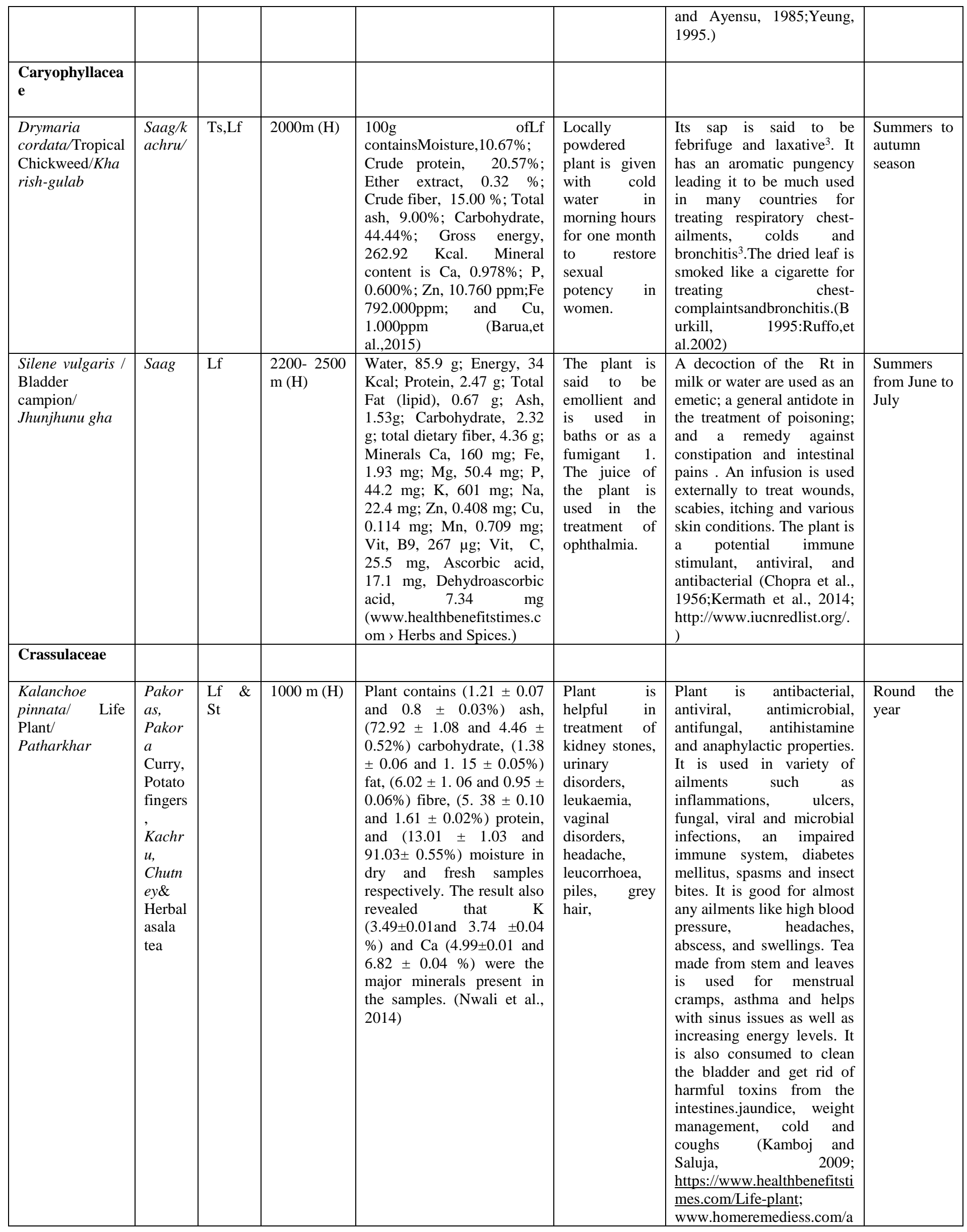




\begin{tabular}{|c|c|c|c|c|c|c|c|}
\hline & & & & & & $\begin{array}{l}\text { yurvedic-plant- } \\
\text { bryophyllum-pinnatum } \\
\text { uses-and-pics) }\end{array}$ & \\
\hline \multicolumn{8}{|l|}{ Combretaceae } \\
\hline $\begin{array}{l}\text { Terminalia } \\
\text { bellirical } \\
\text { Myrobalan/ } \\
\text { Baheda }\end{array}$ & Pickle & $\mathrm{Fr}$ & $1000 \mathrm{~m}(\mathrm{~T})$ & N/A & $\begin{array}{l}\text { The Bk is } \\
\text { mildly and } \\
\text { diuretic and } \\
\text { useful in } \\
\text { anemia and } \\
\text { leucoderma. } \\
\text { The Fr are } \\
\text { astringent, } \\
\text { acrid sweet, } \\
\text { thermogenesis } \\
\text { inflammatory, } \\
\text { anodyne, } \\
\text { styptic, } \\
\text { narcotic, } \\
\text { digestive, } \\
\text { anthelmintic, } \\
\text { and aperient, } \\
\text { experctorant, } \\
\text { ophthalmic, } \\
\text { antipyretic, } \\
\text { antiemetic and } \\
\text { rejuvenating. }\end{array}$ & $\begin{array}{l}\text { They are useful in vitiated } \\
\text { conditions of kapha and } \\
\text { vata, cough, bronchitis, } \\
\text { pharyngitis, insomnia, } \\
\text { dropsy, dyspepsia, } \\
\text { flatulence, dipsia, vomiting, } \\
\text { haemorrhages, } \\
\text { ophthalmopathy, strangury, } \\
\text { splenomegaly. Skin } \\
\text { diseases, leprosy, fevers, } \\
\text { ulcers and general debility1. } \\
\text { The mature and dry fruit is } \\
\text { constipating and is useful in } \\
\text { diarrhea and dysentery. The } \\
\text { oil obtained from the Sd is } \\
\text { trichogenous and is useful } \\
\text { in dyspepsia, skin diseases, } \\
\text { leucoderma and greyness of } \\
\text { hair.(Purohit et al., 2009) }\end{array}$ & $\begin{array}{ll}\mathrm{Fr}= & \\
\text { Autumn } & \text { to } \\
\text { Winter/ } & \\
\text { Churan is } \\
\text { sold } & \text { Rs } \\
50 / 100 \mathrm{~g} . & \end{array}$ \\
\hline $\begin{array}{l}\text { Terminalia } \\
\text { chebula /Black } \\
\text { Myrobalan/ } \\
\text { Harad }\end{array}$ & $\begin{array}{l}\text { Pickle, } \\
\text { Murab } \\
b a, \\
\text { alcoho } \\
\text { lic } \\
\text { Drink }\end{array}$ & Fr & $1500 \mathrm{~m}(\mathrm{~T})$ & & $\begin{array}{l}\text { Fr are laxative } \\
\text { and digestive, } \\
\text { and useful to } \\
\text { treat vitamin } \\
\mathrm{C} \text { deficiency, } \\
\text { cough, fever } \\
\text { in the form of } \\
\text { Triphala } \\
\text { Churan. } \\
\text { Considered to } \\
\text { good } \\
\text { enhance } \\
\text { eyesight \& } \\
\text { manage blood } \\
\text { pressure. . }\end{array}$ & $\begin{array}{l}\text { Fr constitute one of the } \\
\text { 'Triphala' of Ayurveda. Fr } \\
\text { are astringent, sweet, acrid, } \\
\text { bitter, sour, thermogenic, } \\
\text { anodyne, anti- } \\
\text { inflammatory, vulnerary, } \\
\text { alterant, stomachic, and } \\
\text { laxative, purgative, } \\
\text { carminative, digestive, } \\
\text { anthelmintic, cardiotonic, } \\
\text { aphrodisiac, antiseptic, } \\
\text { febrifuge, depurative and } \\
\text { tonic. They are useful in } \\
\text { vitiated conditions of } \\
\text { tridosa wounds ulcers, } \\
\text { inflammations, gastropathy, } \\
\text { anorexia, helminthiasis, } \\
\text { flatulence, haemorrhoids, } \\
\text { jaundice, hepatopathy, } \\
\text { splenopathy, aryou, cough, } \\
\text { uropathy, versical, renal } \\
\text { calculi and cardic } \\
\text { disorder(Purohit et al., } \\
\text { 2009; Singh, 2018) }\end{array}$ & $\begin{array}{l}\mathrm{Fr}=\text { pre } \\
\text { autumn to } \\
\text { mid winter/ } \\
\text { Dried fruits } \\
\mathrm{Rs} 10 / \text { For } 1 \\
\mathrm{~kg} \text { Triphala } \\
\text { Churan Rs } \\
500\end{array}$ \\
\hline \multicolumn{8}{|l|}{ Cucurbitaceae } \\
\hline $\begin{array}{l}\text { Coccinia } \\
\text { grandis/ Ivy } \\
\text { gourd/ Kandiari }\end{array}$ & $\begin{array}{l}\text { Veg, } \\
\text { Veg } \\
\text { curry }\end{array}$ & $\begin{array}{ll}\text { Lf } & \& \\
\text { Ts } & \end{array}$ & $1000 \mathrm{~m}(\mathrm{H})$ & N/A & $\begin{array}{l}\text { Rt are cooling } \\
\text { and } \\
\text { aphrodisiac } \\
\text { and are useful } \\
\text { in vomiting, } \\
\text { burning } \\
\text { sensation and } \\
\text { uterine } \\
\text { discharge. } \\
\text { The juice of } \\
\text { the Rt and Lf } \\
\text { is considered }\end{array}$ & $\begin{array}{l}\text { Lf are bitter, sweet, } \\
\text { astringent and cooling and } \\
\text { are useful in vitiated } \\
\text { conditions of kapha and } \\
\text { pitta. The Fr are cooling, } \\
\text { sweet, astringent, } \\
\text { depurative, and antipyretic, } \\
\text { galactagogue and } \\
\text { expectorant and are useful } \\
\text { in burning sensation, } \\
\text { leprosy, skin diseases, and } \\
\text { fever. Asthma, cough, }\end{array}$ & $\begin{array}{l}\text { Lf round } \\
\text { the year and } \\
\text { fruits from } \\
\text { pre rainy to } \\
\text { winter }\end{array}$ \\
\hline
\end{tabular}




\begin{tabular}{|c|c|c|c|c|c|c|c|}
\hline & & & & & $\begin{array}{l}\text { to be a useful } \\
\text { treatment for } \\
\text { diabetes. }\end{array}$ & $\begin{array}{l}\text { bronchitis, consumption and } \\
\text { jaundice. The fruits and } \\
\text { leaves of the bitter variety } \\
\text { and bitter, acrid, } \\
\text { thermogenic, emetic, } \\
\text { purgative, vulnerary, anti- } \\
\text { inflammatory, anthelmintic, } \\
\text { digestive, liver tonic, } \\
\text { alexiteric, depurative, } \\
\text { febrifuge, sudorific and } \\
\text { expectorant and are useful } \\
\text { in vitiated conditions of } \\
\text { kapha and pitta, wounds } \\
\text { ulcers, inflammation, } \\
\text { helminthiasis, dyspepsia } \\
\text { and hepatopathy. The juice } \\
\text { of the stem is dripped into } \\
\text { the eyes to treat } \\
\text { cataracts.The Lf are used } \\
\text { externally as a poultice in } \\
\text { treating skin eruptions } \\
\text { (Chopra et al., 1956; } \\
\text { Purohit et al., 2009) }\end{array}$ & \\
\hline $\begin{array}{l}\text { Momordica } \\
\text { balaminal } \\
\text { Balsam Pear/ } \\
\text { Van Krela }\end{array}$ & $\begin{array}{l}\text { Porrid } \\
\text { ge, } \\
\text { Pickle } \\
\& \text { Veg }\end{array}$ & $\begin{array}{l}\text { Fr } \quad \& \\
\text { Lf }\end{array}$ & $1500 \mathrm{~m}(\mathrm{H})$ & $\begin{array}{l}\text { Lf on dry weight basis } \\
\text { contain }(\%) \text { moisture, } 71.00 \\
\pm 0.95 ; \text { ash, } 18.00 \pm 0.56 \\
\text { crude protein, } 11.29 \pm 0.07 \\
\text { crude lipid, } 2.66 \pm 0.13 ; \\
\text { crude fiber, } 29.00 \pm 1.23 \\
\text { carbohydrate, } 39.05 \pm 2.01 ; \\
\text { calorific value, }(\mathrm{kcal} / 100 \mathrm{~g}) \\
189.22 ; \mathrm{P} ; 1,320.00 ; \mathrm{Na} \text {, } \\
122.49 ; \mathrm{Ca}, 941 ; \mathrm{Mg} .220 ; \\
\mathrm{P} 130.46 ; \mathrm{Mn}, 11.6 ; \mathrm{Fe}, \\
60.3 ; \mathrm{Cu}, 5.44 ; \mathrm{Zn}, 3.18 ; \\
\mathrm{K} / \mathrm{Na}, 10.78 ; \mathrm{Ca} / \mathrm{P} 7.21 \\
(\mathrm{Hassan} \& \mathrm{Umar}, 2006)\end{array}$ & $\begin{array}{l}\text { Deseeded Fr } \\
\text { are infused in } \\
\text { olive or } \\
\text { almond oil } \\
\text { and used } \\
\text { against burns } \\
\text { and } \\
\text { hemorrhoid's } \\
\text { and the } \\
\text { mashed fruits } \\
\text { are used as a } \\
\text { poultice. }\end{array}$ & $\begin{array}{l}\text { Plant extract is used to in } \\
\text { control hyperglycemia It is } \\
\text { one of the traditional } \\
\text { medicines that have been } \\
\text { used for decades for the } \\
\text { management of diabetes. } \\
\text { High potassium content is a } \\
\text { good source for the } \\
\text { management of } \\
\text { hypertension and other } \\
\text { cardiovascular conditions } \\
\text { (Watt et al., 1962; Gills, } \\
\text { 1992; Otimenyin et al., } \\
\text { 2008.) }\end{array}$ & $\begin{array}{l}\text { leaves and } \\
\text { fruits from } \\
\text { summer end } \\
\text { to and pre } \\
\text { winter }\end{array}$ \\
\hline \multicolumn{8}{|l|}{ Dioscoreaceae } \\
\hline $\begin{array}{l}\text { Dioscorea } \\
\text { pentaphyllal } \\
\text { Buck Yam/ } \\
\text { Dareghal }\end{array}$ & $\begin{array}{l}\text { Bhalle } \\
\text {, Veg, } \\
\text { Dahin } \\
\text { Bhalle } \\
\text { Kachr } \\
\text { Kachu } \\
\text { Kach } \\
\text { ri }\end{array}$ & $\begin{array}{l}\text { Bl, Lf } \\
\& \mathrm{Tu}\end{array}$ & $1500 \mathrm{~m}(\mathrm{H})$ & $\begin{array}{l}\text { Serving Size: } 1 \text { Cup, } 100 \mathrm{~g} \\
\text { Water ,77.14 g; Energy, } 82 \\
\text { Kcal; Protein, } 1.73 \mathrm{~g} \text {; Total } \\
\text { Fat (lipid), } 0.08 \mathrm{~g} \text {; Ash } 1.06 \\
\text { g, Carbohydrate, } 20 \mathrm{~g} \text {; Ca, } 8 \\
\text { mg; Fe, } 0.43 \mathrm{mg} \text {; Mg, } 10 \\
\text { mg; P, } 40 \mathrm{mg} \text { K, } 495 \mathrm{mg} \text {; } \\
\text { Na, } 12 \mathrm{mg} \text { Z Zn, } 0.32 \mathrm{mg}\end{array}$ & Used as tonic & $\begin{array}{l}\text { Tu are applied on swelling } \\
\text { of joints and used as tonic } \\
\text { to improve body immunity, } \\
\text { stomach pain and rheumatic } \\
\text { swellingsInflorescence is } \\
\text { used as vegetables for body } \\
\text { weakness. Tu are useful to } \\
\text { allay pain and swelling } \\
\text { (Kamble andVelhal, }\end{array}$ & $\begin{array}{l}\text { Pre-winter } \\
\text { to spring } \\
\text { season/ } \mathrm{Tu}= \\
250 \text { to } 500 / \\
\mathrm{kg}\end{array}$ \\
\hline
\end{tabular}




\begin{tabular}{|c|c|c|c|c|c|c|c|}
\hline & $\begin{array}{l}\text {,siddu } \\
\& \\
\text { Parant } \\
\text { ha }\end{array}$ & & & 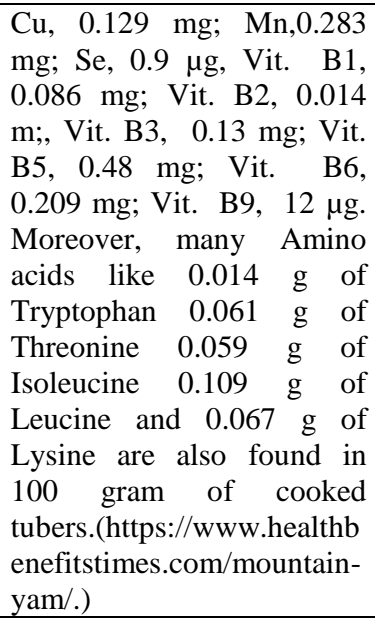 & & 2010;Kumar et al., 2017 ) & \\
\hline \multicolumn{8}{|l|}{ Elaeagnaceae } \\
\hline $\begin{array}{l}\text { Elaeagnus } \\
\text { umbellata / } \\
\text { Autumn Olive/ } \\
\text { Ghayain }\end{array}$ & $\begin{array}{l}\text { Jam, } \\
\text { Desser } \\
\mathrm{t} \quad \& \\
\text { Veg } \\
\text { curry }\end{array}$ & $\begin{array}{l}\text { Fr \& } \\
\text { Sd }\end{array}$ & $\begin{array}{l}1000-3000 \\
\mathrm{~m}(\mathrm{Sh})\end{array}$ & $\begin{array}{l}\text { One } 100 \mathrm{~g} \text { of Fr contains } \\
69.4 \mathrm{~g} \text { of moisture, } 14.5 \mathrm{~g} \\
\text { of total soluble solids, } 1.51 \\
\mathrm{~g} \text { of acids, } 8.34 \mathrm{~g} \text { of total } \\
\text { sugars, } 8.13 \mathrm{~g} \text { of reducing } \\
\text { sugars, } 0.23 \mathrm{~g} \text { of non- } \\
\text { reducing sugars, and } 12.04 \\
\text { mg of vitamin C.The } \\
\text { percentage contents of some } \\
\text { of the mineral elements, viz. } \\
\mathrm{P}, \mathrm{K}, \mathrm{Ca}, \mathrm{Mg} \text { and Fe are } \\
0.054,0.346,0.049,0.033 \\
\text { and } 0.007 \text { in this order } \\
\text { (Parmar and Kaushal, } 1982 \text { ) }\end{array}$ & $\begin{array}{l}\text { Dry powered } \\
\text { Lf and Fr are } \\
\text { helpful in } \\
\text { checking } \\
\text { diarrhoea; } 2 \\
\text { teaspoons } \\
\text { twice daily for } \\
3-4 \text { days. The } \\
\text { Fl are } \\
\text { astringent, } \\
\text { cardiac and } \\
\text { stimulant. } \\
\text { They are used } \\
\text { in the } \\
\text { treatment of } \\
\text { coughs and } \\
\text { pulmonary } \\
\text { infections. }\end{array}$ & $\begin{array}{l}\text { The seeds are used as a } \\
\text { stimulant in the treatment of } \\
\text { coughs. The expressed oil } \\
\text { from the seeds is used in the } \\
\text { treatment of pulmonary } \\
\text { affections. The unripe fruit } \\
\text { is astringent and is eaten in } \\
\text { the treatment of bloody } \\
\text { dysentery. (Chopra et al., } \\
\text { 1956;Sood and Thakur, } \\
\text { 2004;Pallab et al., 2016.) }\end{array}$ & $\begin{array}{l}\text { Summer } \\
\text { season }\end{array}$ \\
\hline \multicolumn{8}{|l|}{ Euphorbiaceae } \\
\hline $\begin{array}{l}\text { Euphorbia } \\
\text { hirta/Asthma } \\
\text { weed/Dudhi }\end{array}$ & $\begin{array}{l}\text { Veg, } \\
\text { Saag, }\end{array}$ & $\begin{array}{ll}\text { Lf } \quad \& \\
\text { St }\end{array}$ & $900 \mathrm{~m}(\mathrm{H})$ & 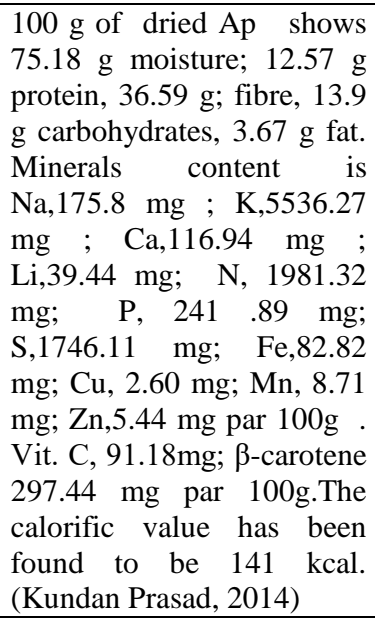 & $\begin{array}{l}\text { Locally given } \\
\text { against piles } \\
\text { \& asthma. }\end{array}$ & $\begin{array}{l}\text { Antidote to snake bite, } \\
\text { asthma, boils of mouth, } \\
\text { kidney disease, pain in } \\
\text { joints, veterinary. bone } \\
\text { fracture, Extracts of E. hirta } \\
\text { have been found to show } \\
\text { anticancer activity } \\
\text { decoction of dry herbs is } \\
\text { used for skin diseases. } \\
\text { (Chopra et a., 1956) }\end{array}$ & $\begin{array}{l}\text { Can be } \\
\text { harvested } \\
\text { from early } \\
\text { summer to } \\
\text { early winter }\end{array}$ \\
\hline \multicolumn{8}{|l|}{ Fabaceae } \\
\hline $\begin{array}{l}\text { Indigofera } \\
\text { heterantha/ } \\
\text { Indigo Bush/ } \\
\text { Kalli kathi }\end{array}$ & $\begin{array}{l}\text { Kchru, } \\
\text { Rayat } \\
\text { a\& } \\
\text { Pickle }\end{array}$ & $\mathrm{Fl}$ & $\begin{array}{l}1000-2800 \\
\mathrm{~m}(\mathrm{Sh})\end{array}$ & N/A & $\begin{array}{l}\text { Powered Rt } \\
\text { heals internal } \\
\text { injuries, half } \\
\text { teaspoon } \\
\text { twice a day } \\
\text { with cow milk } \\
\text { for 5-8 days. }\end{array}$ & $\begin{array}{l}\text { Plant is also considered } \\
\text { useful for cough, muscular } \\
\text { pains and urinary disorders } \\
\text { in animal. Ap are anticance } \\
\text { (Chopra et a., 1956); }\end{array}$ & $\begin{array}{l}\text { flowers } \\
\text { from rainy } \\
\text { to pre } \\
\text { winter } \\
\text { season }\end{array}$ \\
\hline $\begin{array}{l}\text { Lathyrus } \\
\text { aphaca/ Yellow }\end{array}$ & $\begin{array}{l}\text { Saag\& } \\
\text { Veg }\end{array}$ & $\begin{array}{l}\text { Ts, } \\
\text { Pod\& }\end{array}$ & $\begin{array}{ll}2200 & \text { m } \\
(\mathrm{Sh}) & \\
\end{array}$ & $\begin{array}{l}\text { The seed contains around } \\
23.5 \% \text { crude protein, } 15.2 \%\end{array}$ & $\begin{array}{l}\text { The ripe } \mathrm{Sd} \\
\text { are believed }\end{array}$ & $\begin{array}{l}\text { Powdered Sd are used to } \\
\text { cure cough \& diarrhoea. Sd }\end{array}$ & $\begin{array}{l}\text { Summer to } \\
\text { rainy season }\end{array}$ \\
\hline
\end{tabular}




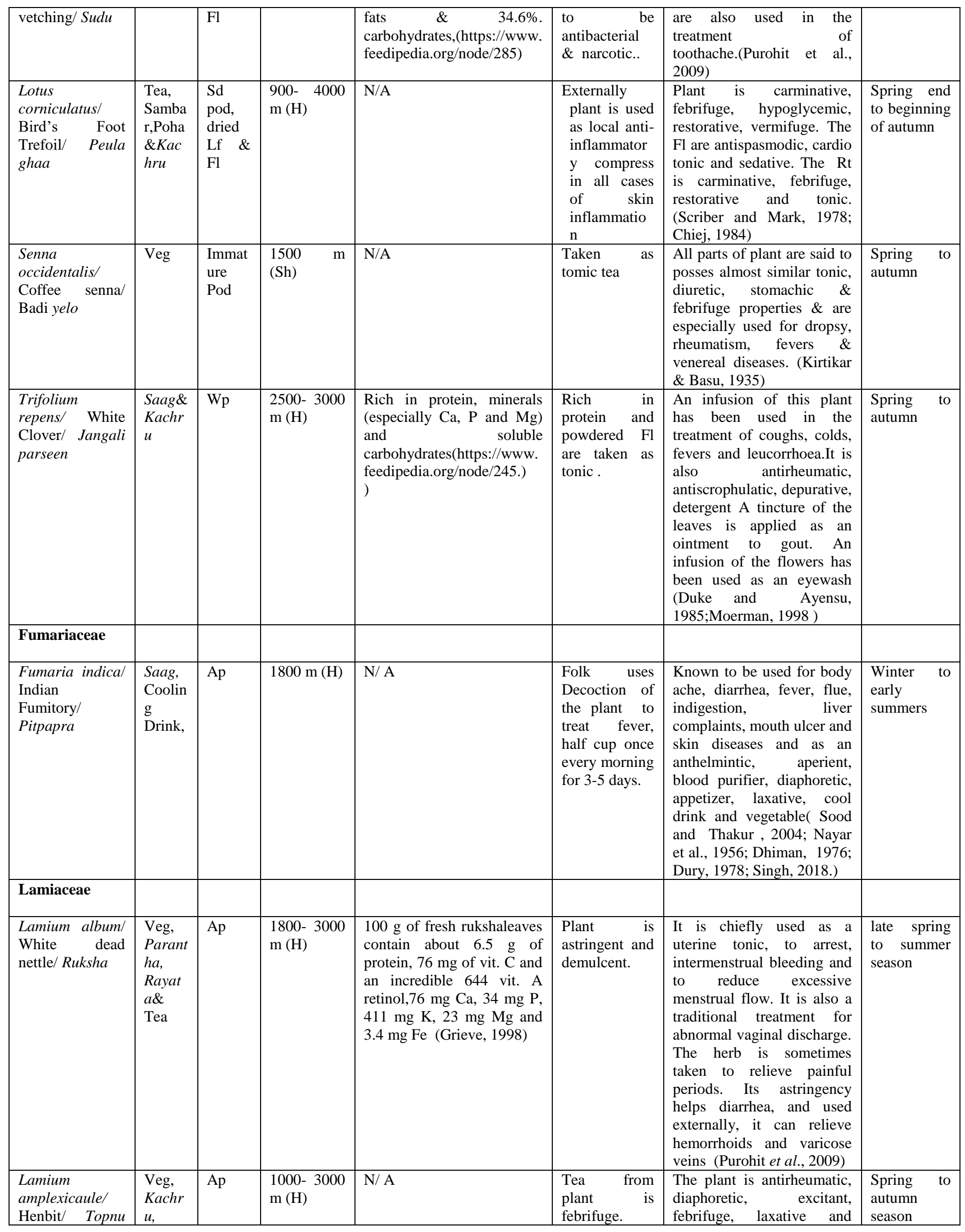




\begin{tabular}{|c|c|c|c|c|c|c|c|}
\hline ghaa & $\begin{array}{l}\text { Rayat } \\
\text { a\& tea }\end{array}$ & & & & & $\begin{array}{l}\text { stimulant } \\
\text { (Chopra et al., 1956;Duke } \\
\text { and Ayensu, 1985) }\end{array}$ & \\
\hline $\begin{array}{l}\text { Mentha } \\
\text { longifolia/ Lamb } \\
\text { mint/Jangli } \\
\text { Pudina }\end{array}$ & $\begin{array}{l}\text { Masal } \\
\text { a Tea } \\
\& C h u t \\
\text { ney }\end{array}$ & Ap & $\begin{array}{l}1200-3000 \\
\mathrm{~m}(\mathrm{H})\end{array}$ & 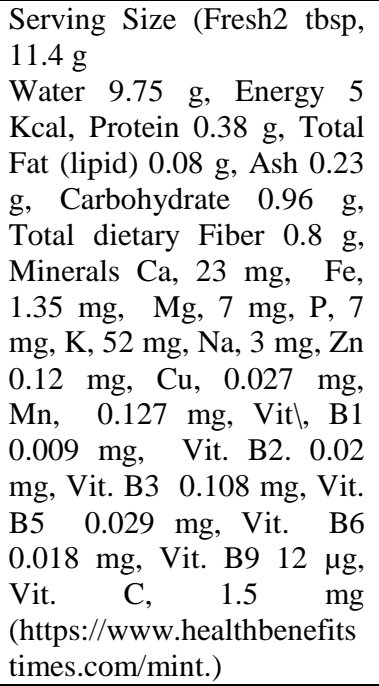 & $\begin{array}{l}\text { Decoction is } \\
\text { used to treat } \\
\text { coughs, colds, } \\
\text { asthma and } \\
\text { other } \\
\text { respiratory } \\
\text { ailments like, } \\
\text { headaches, } \\
\text { fever, } \\
\text { indigestion, } \\
\text { flatulence etc. }\end{array}$ & $\begin{array}{l}\text { Powered plant parts are } \\
\text { useful in general eye } \\
\text { diseases, half - one g twice } \\
\text { a day for } 8-10 \text { days. The } \\
\text { plant is astringent to the } \\
\text { bowel, anthelmintic, useful } \\
\text { in diseases ofthe heart, } \\
\text { bronchitis, loss of appetite, } \\
\text { diarrhea and } \\
\text { dysentery(Kirtikar \& Basu, } \\
\text { 1935;Sood \& Thakur, 2004 } \\
\text { ) }\end{array}$ & $\begin{array}{l}\text { Fl between } \\
\text { September } \\
\text { to } \\
\text { November }\end{array}$ \\
\hline $\begin{array}{l}\text { Origanum } \\
\text { vulgare/ Wild } \\
\text { Marjoran/ } \\
\text { Bantulsi }\end{array}$ & $\begin{array}{l}\text { Chutn } \\
\text { ey, } \\
\text { Kachr } \\
\text { u\& } \\
\text { Masal } \\
\text { a Tea }\end{array}$ & Lf & $\begin{array}{l}1000-3000 \\
\mathrm{~m}(\mathrm{H})\end{array}$ & 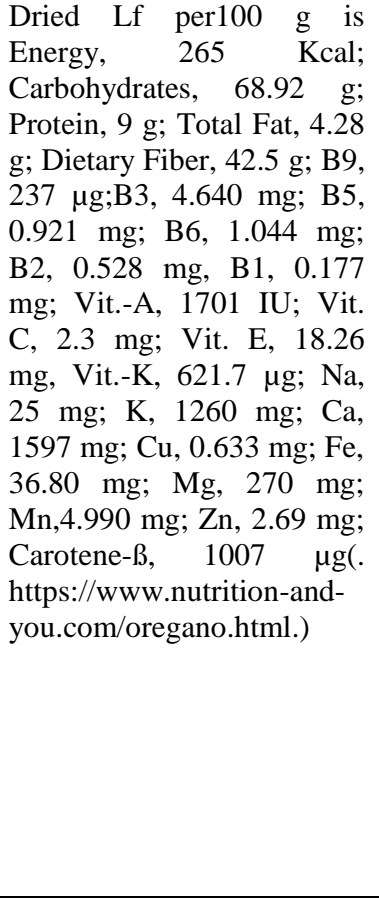 & $\begin{array}{l}\text { Warm } \\
\text { infusion of } \\
\text { herb is given } \\
\text { to promote- } \\
\text { menstrual } \\
\text { flow when } \\
\text { suppressed by } \\
\text { cold. }\end{array}$ & $\begin{array}{l}\text { Plant is useful to settle } \\
\text { flatulence and stimulates } \\
\text { the flow of bile. Strongly } \\
\text { antiseptic, it may be taken } \\
\text { to treat respiratory } \\
\text { conditions such as coughs, } \\
\text { tonsillitis, bronchitis and } \\
\text { asthma. Volatile oil } \\
\text { obtained from plant is } \\
\text { aromatic, stimulant, } \\
\text { rubifacient and tonic; useful } \\
\text { in colic, diarrhoea, hysteria, } \\
\text { rheumatism and toothache. } \\
\text { The diluted oil can applied } \\
\text { to toothache or painful } \\
\text { joints. Locally, the tablet } \\
\text { made from leaves is } \\
\text { administered orally in bone } \\
\text { fractures. The paste of the } \\
\text { Lf is applied in fire burns, } \\
\text { eczematous skin, boils, cuts } \\
\text { and wounds (Bown, } \\
\text { 1995;Chauhan, 1999; } \\
\text { Purohit et al., 2009; Singh, } \\
\text { 2018) }\end{array}$ & $\begin{array}{l}\text { Spring to } \\
\text { summer }\end{array}$ \\
\hline $\begin{array}{l}\text { Prunella } \\
\text { vulgaris/ Self- } \\
\text { heal/ } \quad \text { Neela } \\
\text { ghoongru ghaa }\end{array}$ & $\begin{array}{l}\text { Saag, } \\
\text { Siddu, } \\
\text { Kachr } \\
u \quad \text { or } \\
\text { sosaru } \\
\text {, Soup } \\
\& \\
\text { Refres } \\
\text { hing } \\
\text { summ } \\
\text { er } \\
\text { drink }\end{array}$ & $\mathrm{Wp}$ & $\begin{array}{l}2600-3000 \\
\mathrm{~m}(\mathrm{H})\end{array}$ & N/ A & $\begin{array}{l}\text { Plant is } \\
\text { helpful to } \\
\text { treat dizziness } \\
\text { due to } \\
\text { hypertension; } \\
\text { headache; } \\
\text { tinnitus; } \\
\text { conjunctivitis, } \\
\text { dry cough, } \\
\text { skin inflammation } \\
\text { and boils. }\end{array}$ & $\begin{array}{l}\text { Plant is an expectorant } \\
\text { (used to get relief from } \\
\text { cough) and antispasmodic ( } \\
\text { cure muscle spasm.The } \\
\text { whole plant is alterative, } \\
\text { antibacterial, antipyretic, } \\
\text { antiseptic, antispasmodic, } \\
\text { astringent, carminative, } \\
\text { diuretic, } \\
\text { hypotensive, stobrifuge, } \\
\text { styptic (Stopbleeding),tonic, } \\
\text { vermifuge and vulnerary } \\
\text { (Launert, 1981; Grieve, } \\
\text { 1984;) }\end{array}$ & $\begin{array}{l}\text { Summers to } \\
\text { autumn/ }\end{array}$ \\
\hline $\begin{array}{l}\text { Salvia } \\
\text { moorcroftiana / } \\
\text { Kashmir Salvia/ } \\
\text { Shobri }\end{array}$ & $\begin{array}{l}\text { Veg \& } \\
\text { Soup }\end{array}$ & $\mathrm{St}$ & $\begin{array}{l}1000-2600 \\
\mathrm{~m}(\mathrm{H})\end{array}$ & N/A & $\begin{array}{l}\text { Rt yields } \\
\text { essential oil, } \\
\text { used in cold \& } \\
\text { cough. }\end{array}$ & $\begin{array}{l}\text { Lf are used against guinea- } \\
\text { worm \& are applied as } \\
\text { poultics for boils, wounds } \\
\& \text { chronic affections of the } \\
\text { skin. Sd are considered } \\
\text { useful in hemorrhoids, }\end{array}$ & \\
\hline
\end{tabular}




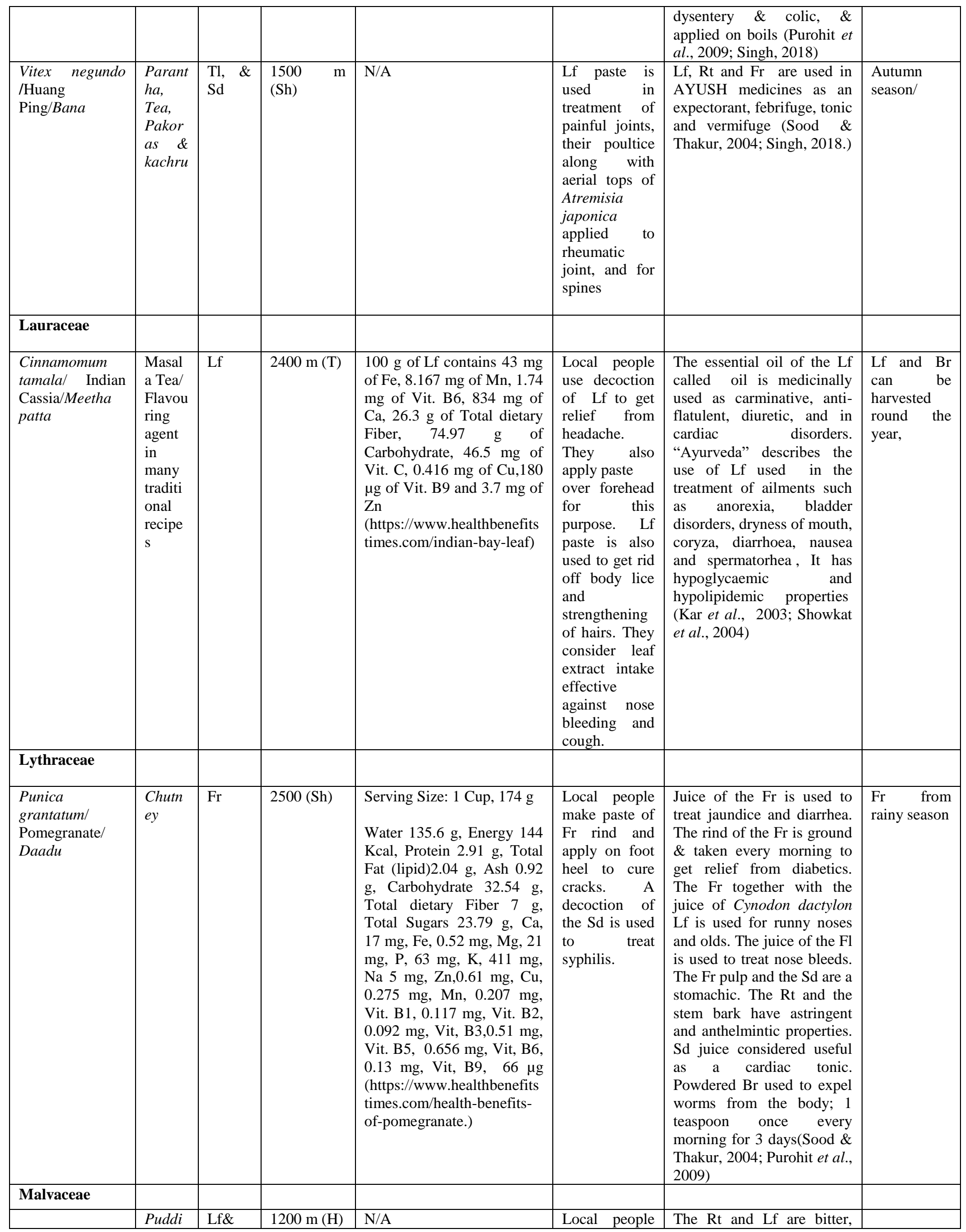




\begin{tabular}{|c|c|c|c|c|c|c|c|}
\hline $\begin{array}{l}\text { Sida } \\
\text { cordifolia/Broo } \\
\text { m Jute/Dridh }\end{array}$ & $\begin{array}{l}\text { ngs, } \\
\text { Rehdo } \\
\text { o, } \\
\text { Laddu } \\
\text { Kheer } \\
\& \\
\text { Tonic } \\
\text { Tea } \\
\text { from } \\
\text { Lf }\end{array}$ & $\mathrm{Sd}$ & & & $\begin{array}{l}\text { use Lf \& Sd } \\
\text { as a tonic by } \\
\text { taking asa tea } \\
\text { or cooking } \\
\text { into } \\
\text { vegetable. }\end{array}$ & $\begin{array}{l}\text { sweet, emollient, cooling, } \\
\text { aphrodisiac, unctuous, and } \\
\text { vigour strengthening and } \\
\text { promote sexual vigour and } \\
\text { vital factor. They are good } \\
\text { for rheumatism, flatulence, } \\
\text { colic, haemothermia, and } \\
\text { emaciation, vitiated } \\
\text { conditions of tridosa, } \\
\text { seminal weakness, arthritis } \\
\text { and diarrhoea(Purohit et al., } \\
\text { 2009; Sood \& Thakur, } \\
\text { 2004) }\end{array}$ & \\
\hline \multicolumn{8}{|l|}{$\begin{array}{l}\text { Menispermacea } \\
\text { e }\end{array}$} \\
\hline $\begin{array}{l}\text { Tinospora } \\
\text { cordifolial } \\
\text { Amrita/ Gulje }\end{array}$ & $\begin{array}{l}\text { Halwa } \\
\text {, Sirra }\end{array}$ & $\begin{array}{l}\text { St, Rt } \\
\& \mathrm{Br}\end{array}$ & $1400 \mathrm{~m}(\mathrm{H})$ & $\begin{array}{l}100 \mathrm{~g} \text { of } \mathrm{St} \text { contain } \\
\text { approximately } \\
3.34 \mathrm{~g} \text { carbohydrate, } 2.30 \mathrm{~g} \\
\text { protein, } 11.321 \mathrm{~g} \text { fibre, } 5.87 \\
\text { milligrams iron, } 85.247 \\
\text { milligrams Ca, } 303.7 \\
\text { microgram vitamin A, } 56 \\
\text { milligrams vitamin } \mathrm{C} \\
\text { (https://www.boldsky.com/ } \\
\text { health/nutrition/2018/. () }\end{array}$ & $\begin{array}{l}\text { The St, Rt and } \\
\text { whole plant } \\
\text { are alterative, } \\
\text { antidote, } \\
\text { aphrodisiac, } \\
\text { diuretic, } \\
\text { febrifuge and } \\
\text { tonic. }\end{array}$ & $\begin{array}{l}\text { The starch obtained from } \\
\text { the St and Rt of the plant is } \\
\text { nutrient and is useful in the } \\
\text { treatment of diarrhoea and } \\
\text { dysentery.The fresh plant is } \\
\text { more effective than the } \\
\text { dried. } \\
\text { Plant is also used to treat } \\
\text { rheumatism, urinary } \\
\text { disease, general debility, } \\
\text { bronchitis and infertility. It } \\
\text { is useful in vitiated } \\
\text { conditions of vata, burning } \\
\text { sensation, hyperdipsia, } \\
\text { helminthiasis, dyspepsia, } \\
\text { flatulence, stomachalgia, } \\
\text { intermittent fevers, chronic } \\
\text { fevers, inflammations, gout, } \\
\text { vomitting, cardiac debility, } \\
\text { skin diseases, leprosy, } \\
\text { erysipelas, anaemia, cough, } \\
\text { asthma, general debility, } \\
\text { jaundice, seminal weakness, } \\
\text { uropathy and splenopathy. } \\
\text { Stem: Bitter, astringent, } \\
\text { sweet, thermogenic, } \\
\text { anodyne, anthelmintic, } \\
\text { alterant, antiperoidic, } \\
\text { antispasmodic, antipyretic, } \\
\text { inflammatory, antipestive, } \\
\text { antiemetic, digestive appetise, } \\
\text { carminative, anstipating, } \\
\text { stomachic, constive } \\
\text { cardiotonic, depurative, } \\
\text { heamatinic, expectorant, } \\
\text { aphrodisiac, rejuvenating, } \\
\text { galacto-purifier } \\
\text { tonic.(Gamble,1972;.Kapoo } \\
\text { r,2001;tropical.theferns.info } \\
\text { /viewtropical.php?id=Tinos } \\
\text { pora+cordifolia ) }\end{array}$ & $\begin{array}{l}\text { Round the } \\
\text { year }\end{array}$ \\
\hline \multicolumn{8}{|l|}{ Moraceae } \\
\hline $\begin{array}{lr}\text { Ficus } & \text { hispidal } \\
\text { Hairy } & \text { Fig/ } \\
\text { Debre } & \end{array}$ & $\begin{array}{l}\text { Veg, } \\
\text { Veg } \\
\text { curry. } \\
\text { Parant } \\
\text { hs, } \\
\text { kachur } \\
i\end{array}$ & $\mathrm{Fr}$ & $\begin{array}{l}1100 \\
(\mathrm{~T})\end{array}$ & N/A & $\begin{array}{l}\text { All parts are } \\
\text { bitter, cooling, } \\
\text { acrid; } \\
\text { astringent to } \\
\text { the bowels, } \\
\text { anti-dicentric; } \\
\text { useful } \\
\text { "Kapha", }\end{array}$ & $\begin{array}{l}\text { Fr is sweetish, cooling; } \\
\text { aphrodisiac, tonic, } \\
\text { lactagogue, emetic; causes } \\
\text { "vata" \& constipation. The } \\
\text { The fruit, seed \& bark are } \\
\text { possessed of valuable } \\
\text { emetic properties. ((Purohit } \\
\text { et al., 2009) }\end{array}$ & \\
\hline
\end{tabular}




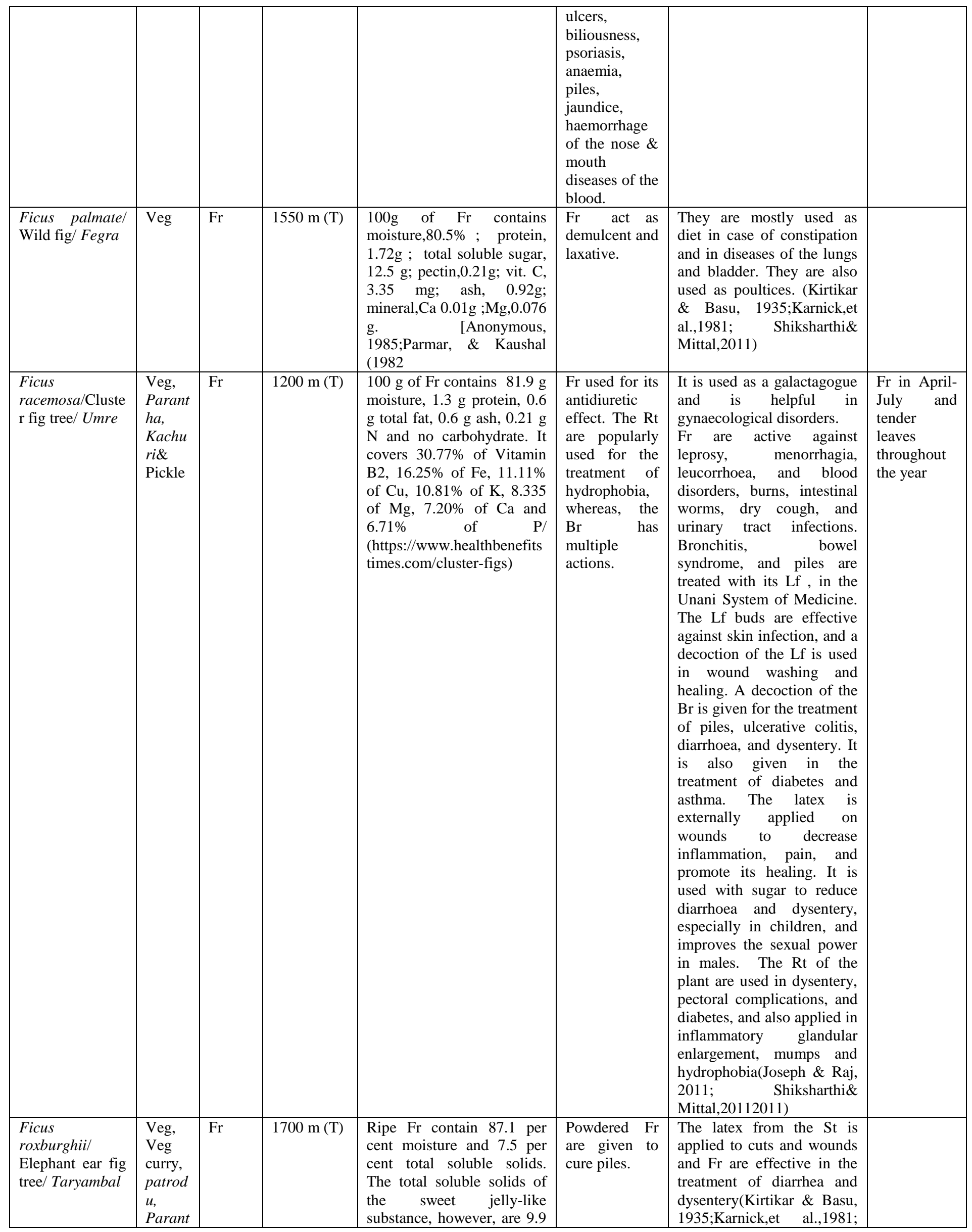




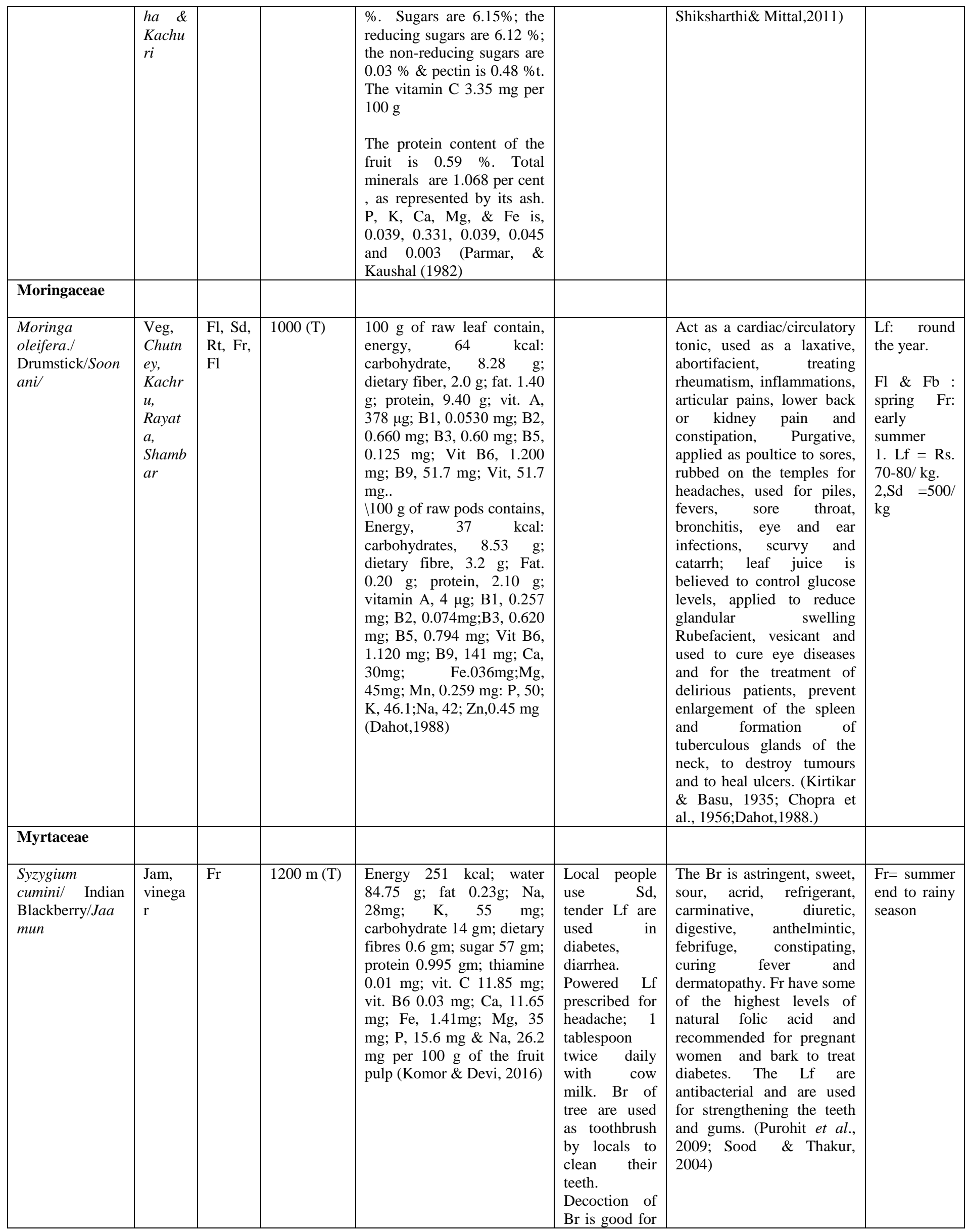




\begin{tabular}{|c|c|c|c|c|c|c|c|}
\hline & & & & & $\begin{array}{l}\text { removing } \\
\text { kidney stones; } \\
3 \text { tablespoons } \\
\text { thrice a day } \\
\text { for } 15-20 \\
\text { days. }\end{array}$ & & \\
\hline \multicolumn{8}{|l|}{ Oxalidaceae } \\
\hline $\begin{array}{l}\text { Oxalis } \\
\text { corniculatal } \\
\text { Creeping } \\
\text { woodsorrel/ } \\
\text { Malori }\end{array}$ & $\begin{array}{l}\text { Chutn } \\
\text { ey, } \\
\text { Veg } \\
\& \\
\text { Refere } \\
\text { shing } \\
\text { summ } \\
\text { er } \\
\text { drink }\end{array}$ & $\begin{array}{l}\text { Lf\& } \\
\text { Fr }\end{array}$ & $3000 \mathrm{~m}(\mathrm{H})$ & $\begin{array}{l}\text { Lf contains } 86 \% \text { water, } \\
2.3 \% \text { protein, } 0.8 \% \text { fat, } \\
8.2 \% \text { carbohydrate, } 150 \mathrm{mg} \\
\mathrm{Ca}, 78 \mathrm{mg} \mathrm{P}, 8 \mathrm{mg} \mathrm{Fe}, 0.6 \\
\mathrm{mg} ; \mathrm{B} 3,78 \mathrm{mg} \text { vit. C, } 6050 \\
\mu \mathrm{g} \text { beta \& } 7-12 \% \\
\text { oxalate(Anonymous, } 1985 \text { ) }\end{array}$ & $\begin{array}{l}\text { Plant is a rich } \\
\text { source of } \\
\text { vitamin C \& } \\
\text { is used in the } \\
\text { treatment of } \\
\text { scurvy. } \\
\text { Powdered } \\
\text { plant given to } \\
\text { check } \\
\text { vomiting \& } \\
\text { nausea. The } \\
\text { infusion of } \\
\text { plant is useful } \\
\text { remedy for } \\
\text { hookworms \& } \\
\text { leaves extract } \\
\text { cure skin } \\
\text { rashes. }\end{array}$ & $\begin{array}{l}\text { Whole plant possesses } \\
\text { various medicinal properties } \\
\text { like anthelmintic, } \\
\text { astringent, antiscorbutic, } \\
\text { diuretic, } \\
\text { febrifuge \& styptic (Bown, } \\
\text { 1995) }\end{array}$ & $\begin{array}{l}\text { Round the } \\
\text { year / }\end{array}$ \\
\hline $\begin{array}{l}\text { Oxalis debilis } \\
\text { var. corymbosal } \\
\text { Lilac } \\
\text { Oxalis/Malora } \\
\text { ghaa }\end{array}$ & $\begin{array}{l}\text { Veg, } \\
\text { Chutn } \\
\text { ey, } \\
\text { Refres } \\
\text { hing } \\
\text { Summ } \\
\text { er } \\
\text { Drink }\end{array}$ & $\begin{array}{l}\text { Lf\& } \\
\text { Fl }\end{array}$ & $1000 \mathrm{~m}(\mathrm{H})$ & N/A & $\begin{array}{l}\text { Refreshing } \\
\text { drink fron Lf } \\
\text { is useful } \\
\text { against cold. }\end{array}$ & & $\begin{array}{l}\text { Spring to } \\
\text { pre- } \\
\text { summers/ }\end{array}$ \\
\hline \multicolumn{8}{|l|}{ Phyllanthaceae } \\
\hline $\begin{array}{l}\text { Phyllanthus } \\
\text { emblica/ Indian } \\
\text { Gooseberry/ } \\
\text { Ambla }\end{array}$ & $\begin{array}{l}\text { Pickle, } \\
\text { Murab } \\
\text { ba, } \\
\text { Jam, } \\
\text { Bhale } \\
\text { and } \\
\text { Badiy } \\
\text { an/, } \\
\text { Ambla } \\
\text { Candy }\end{array}$ & $\mathrm{Fr}$ & $1500 \mathrm{~m}(\mathrm{~T})$ & $\begin{array}{l}100 \mathrm{~g} \text { of raw fruits contains } \\
\text { carbohydrates, } 10 \mathrm{~g} \text {; } \\
\text { moisture, 86g; fats, 0.5g; } \\
\text { protein,1g; gallic acid, } \\
\text { 3012.5mg; Vit. C, } 478 \mathrm{mg} \text {; } \\
\mathrm{E}, 0.16 \mathrm{mg} \text {; Ca, } 25 \mathrm{mg} ; \mathrm{Fe} \text {, } \\
0.9 \mathrm{mg} \text {; } \mathrm{Mg}, 10 \mathrm{mg} ; \mathrm{P}, 21 \\
\mathrm{mg} \text { K }, 198 \mathrm{mg} ; \mathrm{Na}, 13 \mathrm{mg} ; \\
\mathrm{Zn} \quad 0.12 \quad \mathrm{mg} \text {; Cl, } \\
25.6 \mathrm{~m} \text { (Santhi et al., 2007) }\end{array}$ & $\begin{array}{l}\text { Local people } \\
\text { use powdered } \\
\text { Fr to check } \\
\text { baldness and } \\
\text { hair fall along } \\
\text { with mustered } \\
\text { oil heated in } \\
\text { slow flame. } \\
\text { Amla inhibit } \\
\text { the growth } \\
\text { and spread of } \\
\text { different types } \\
\text { of cancer like, } \\
\text { breast, } \\
\text { pancreases, } \\
\text { liver, } \\
\text { uterus,stomac } \\
\mathrm{h} \text { and } \\
\text { malignant as } \\
\text { cites. It also } \\
\text { reduces the }\end{array}$ & $\begin{array}{l}\text { The Br is useful in } \\
\text { gonorrhoea, diarrhoea and } \\
\text { myalgia. The Lf are useful } \\
\text { in conjunctivitis, } \\
\text { inflammation, dyspepsia, } \\
\text { diarrhoea and dysentery. } \\
\text { The Fr are sour, astringent, } \\
\text { bitter, acrid, sweet, cooling, } \\
\text { anodyne, ophthalmic, } \\
\text { carminative, digestive, } \\
\text { stomachic, laxative, } \\
\text { adulterant, alexiteric, } \\
\text { aphrodisiac, diuretic, } \\
\text { antipyretic, tonic. They are } \\
\text { useful in vitiated conditions } \\
\text { of tridosa; diabetes, cough, } \\
\text { asthma, bronchitis, ulcer, } \\
\text { skin diseases, leprosy, } \\
\text { inflammations, anaemia, } \\
\text { jaundice.(Purohit et al., } \\
\text { 2009) }\end{array}$ & $\begin{array}{ll}\text { Fr from } & \text { pre } \\
\text { winter to } \\
\text { end } & \text { of } \\
\text { winter } & \\
\text { season } & \end{array}$ \\
\hline
\end{tabular}




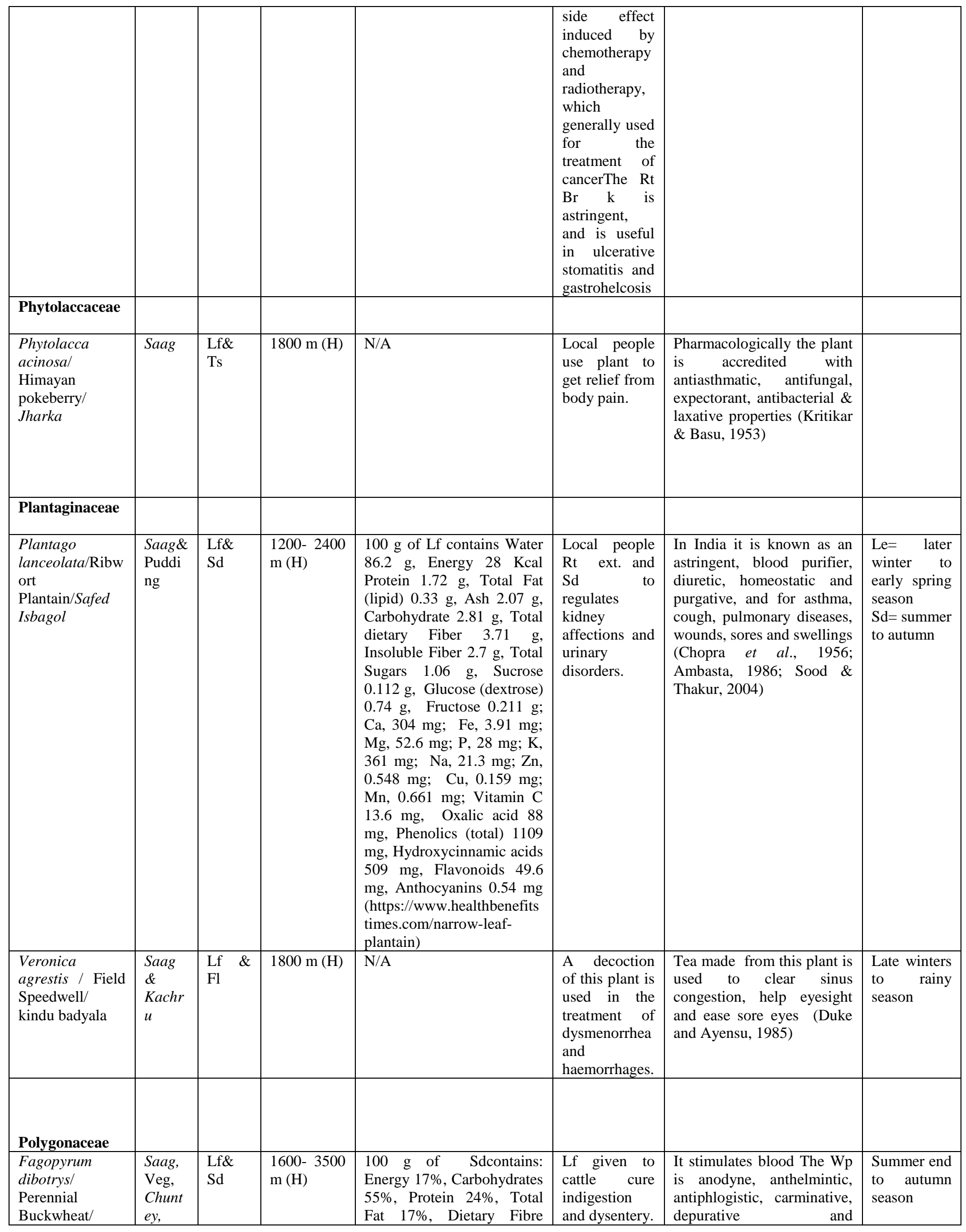




\begin{tabular}{|c|c|c|c|c|c|c|c|}
\hline Kathu & $\begin{array}{l}\text { Babru } \\
\text { or } \\
\text { gulgul } \\
e \\
\text { Kachr } \\
u, \& \\
\text { Tea }\end{array}$ & & & $\begin{array}{l}26 \%, \text { Vit.B9, } 7.5 \% ; \text { NB3, } \\
44 \%, \text { B5, 25\%, B2, 33\%, } \\
\text { B1, 8.5\%, Minerals Ca 2\%, } \\
\text { Cu,122\%, Fe, 27.5\%, Mg } \\
58 \%, \text { Mn 56.5\%, P 50 \%, } \\
\text { Se15\%, Zn 22\% } \\
\text { www.naturalmedicinalherbs } \\
\text {.net/herbs/f/fagopyrum }\end{array}$ & & $\begin{array}{l}\text { febrifuge.circulation. A } \\
\text { decoction issued in the } \\
\text { treatment of traumatic } \\
\text { injuries, lumbago, } \\
\text { menstrual irregularities, } \\
\text { purulent infections, snake } \\
\text { and insect bites. The Lf are } \\
\text { rich in rutin which is a } \\
\text { capillary tonic, antioedemic, } \\
\text { anti-inflammatory, } \\
\text { antispasmodic and } \\
\text { hypotensive (Landy, 1977; } \\
\text { Duke and Ayensu, 1985;) }\end{array}$ & \\
\hline $\begin{array}{l}\text { Fagopyrum } \\
\text { esculentum/ } \\
\text { Buckwheat/ } \\
\text { Phaphra }\end{array}$ & $\begin{array}{l}\text { Saag, } \\
\text { Veg, } \\
\text { Chunt } \\
\text { ey, } \\
\text { Babru } \\
\text { or } \\
\text { gulgul } \\
e \\
\text { Kachr } \\
\text { u, \& } \\
\text { Tea }\end{array}$ & $\begin{array}{l}\text { Lf } \\
\& S d\end{array}$ & $\begin{array}{l}2000-3000 \\
\mathrm{~m}(\mathrm{H})\end{array}$ & 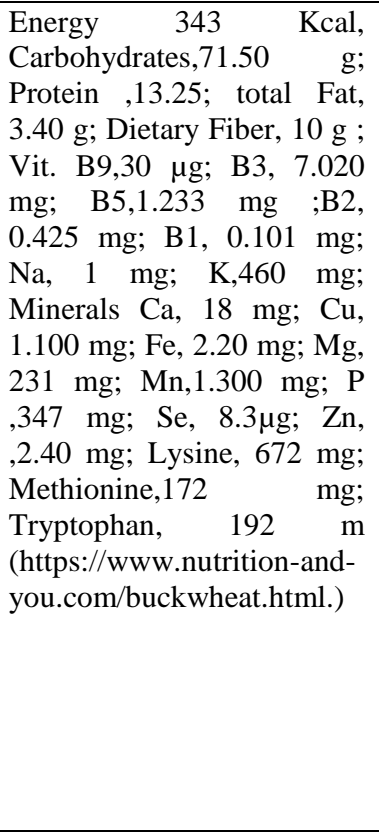 & $\begin{array}{l}\text { Used for a } \\
\text { wide range of } \\
\text { circulatory } \\
\text { problems. }\end{array}$ & $\begin{array}{l}\text { It is used particularly to } \\
\text { treat fragile capillaries, but } \\
\text { also helps strengthen } \\
\text { varicose veins and hea1. } \\
\text { Taken in combination with } \\
\text { other herbs for high blood } \\
\text { pressure. The Lf and shoots } \\
\text { of flowering plants are } \\
\text { acrid, astringent and } \\
\text { vasodilator. A poultice } \\
\text { made from the Sd has been } \\
\text { used for restoring the flow } \\
\text { of milk in nursing mothers. } \\
\text { An infusion of the herb has } \\
\text { been used in the treatment } \\
\text { of acute infectious skin } \\
\text { disease. A homeopathic } \\
\text { remedy has been made from } \\
\text { the leaves. It is used in the } \\
\text { treatment of eczema and } \\
\text { liver disorders (Grieve, } \\
\text { 1984;Purohit et al., 2009; } \\
\text { Sajid et al., 2015 }\end{array}$ & $\begin{array}{l}\text { spring to } \\
\text { summer/ } \\
\text { Leaves= 30- } \\
40 \mathrm{Kg}\end{array}$ \\
\hline \multicolumn{8}{|l|}{ Rhamnaceae } \\
\hline $\begin{array}{l}\text { Ziziphus } \\
\text { mauritianal } \\
\text { Indian Jujube/ } \\
\text { Baer }\end{array}$ & $\begin{array}{l}\text { Badiy } \\
\text { an,Ka } \\
\text { chru\& } \\
\text { alcoho } \\
\text { lic } \\
\text { Drink }\end{array}$ & Fr & $\begin{array}{l}1800 \\
(\mathrm{Sh})\end{array}$ & 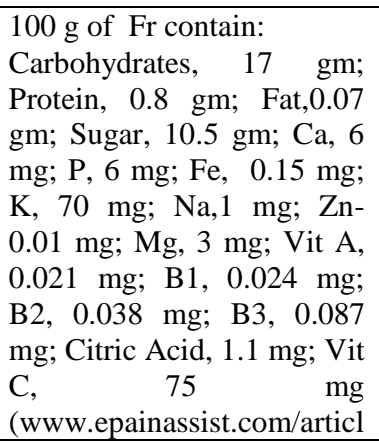 & $\begin{array}{l}\text { The Rt are } \\
\text { bitter, cooling } \\
\text { tonic \& are } \\
\text { useful in } \\
\text { vitiated } \\
\text { conditions of } \\
\text { pitta, fever, } \\
\text { wounds \& } \\
\text { ulcers. }\end{array}$ & 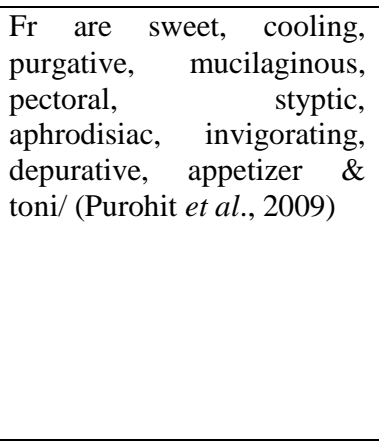 & $\begin{array}{lr}\mathrm{Fr}= & \text { winter } \\
\text { end } & \text { to } \\
\text { spring } & \\
\mathrm{Lf}= & \text { pre- } \\
\text { spring } & \text { to } \\
\text { start } & \text { of } \\
\text { autumn } & \end{array}$ \\
\hline
\end{tabular}




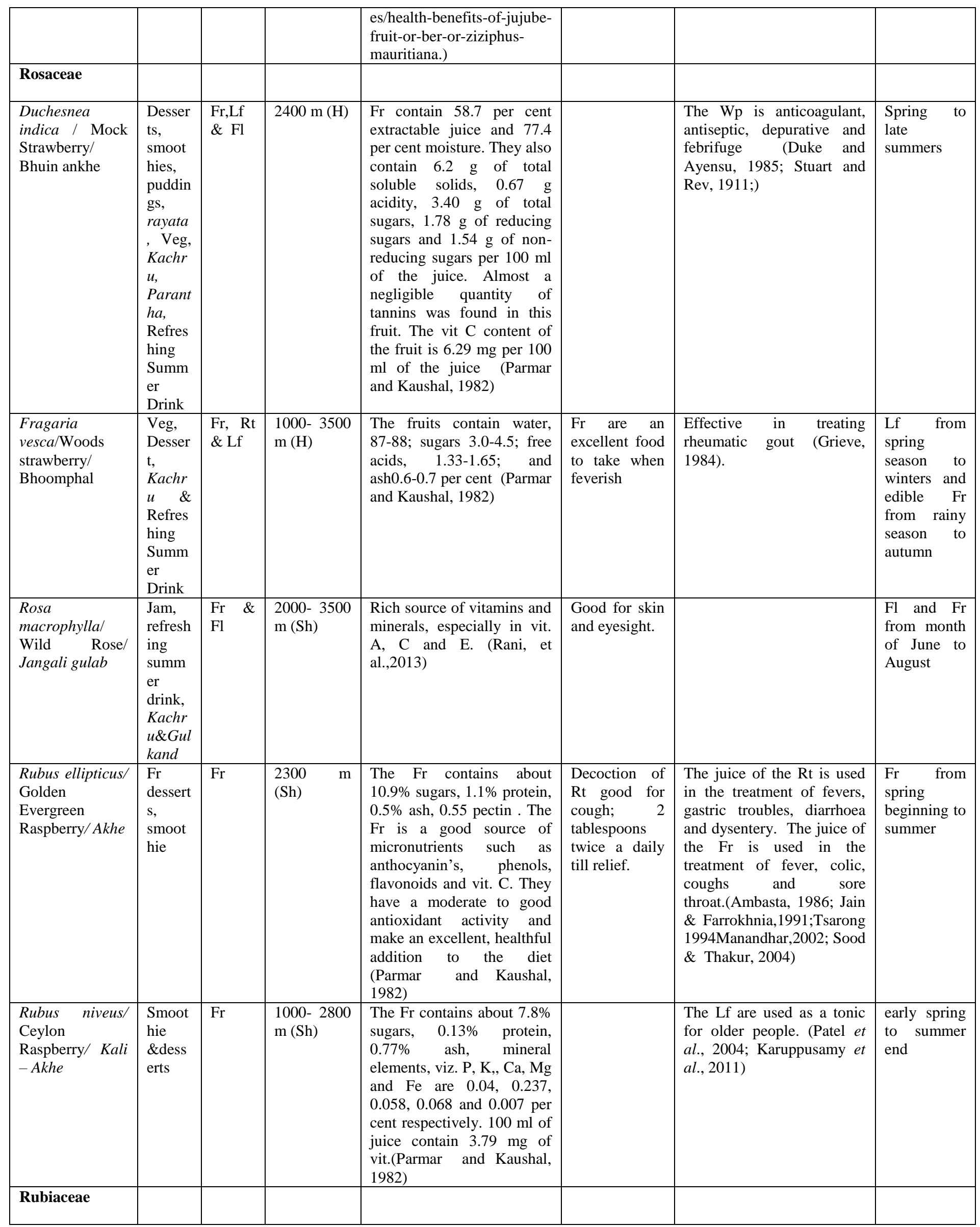




\begin{tabular}{|c|c|c|c|c|c|c|c|}
\hline $\begin{array}{l}\text { Galium aparin / } \\
\text { Goosegrass/ } \\
\text { Kuri }\end{array}$ & $\begin{array}{l}\text { Veg, } \\
\text { Chutn } \\
\text { ey, } \\
\text { Kachr } \\
u, \text { Tea, } \\
\text { Coffee } \\
\text { \& } \\
\text { Laddu }\end{array}$ & $\begin{array}{l}\text { Lf \& } \\
\text { Sd }\end{array}$ & $3000 \mathrm{~m}(\mathrm{H})$ & $\mathrm{N} / \mathrm{A}$ & $\begin{array}{l}\text { Locally it is } \\
\text { considered a } \\
\text { blood } \\
\text { cleanser, good } \\
\text { for tightening } \\
\text { the skin and } \\
\text { reducing sign } \\
\text { of aging. }\end{array}$ & $\begin{array}{l}\text { Herb is dried and pulverized } \\
\text { for use in cough and urinary } \\
\text { disorders; } 1-3 \mathrm{~g} \text { twice a day } \\
\text { for 5-7 days. So, far it is } \\
\text { known in India as an } \\
\text { aperient, diuretic, } \\
\text { refrigerant and } \\
\text { antiscorbutic, and as a } \\
\text { substitute for coffee. The } \\
\text { juice and the infusion are } \\
\text { also taken for kidney stones } \\
\text { and other urinary problem } \\
\text { (Ambasta, 1986;Sood and } \\
\text { Thakur, 2004; Purohit et al., } \\
\text { 2009) }\end{array}$ & $\begin{array}{l}\text { Late winter } \\
\text { to spring } \\
\text { season }\end{array}$ \\
\hline \multicolumn{8}{|l|}{ Rutaceae } \\
\hline $\begin{array}{l}\text { Citrus } \\
\text { aurantium var. } \\
\text { Khatta/Gambhr } \\
\text { u khatta. }\end{array}$ & $\begin{array}{l}\text { Chach } \\
a, \quad \& \\
\text { Pickle }\end{array}$ & Fr & $2500(\mathrm{Sh})$ & NA & $\begin{array}{l}\text { Cure cold and } \\
\text { cough. }\end{array}$ & & \\
\hline $\begin{array}{l}\text { Citrus } \\
\text { pseudolimon/ } \\
\text { Hill lemon/ } \\
\text { Galgal }\end{array}$ & $\begin{array}{l}\text { Chach } \\
a \text {, } \\
\text { Chukh } \\
\& \\
\text { Pickle } \\
\end{array}$ & Fr & $\begin{array}{l}3000 \mathrm{~m} \\
(\mathrm{~T})\end{array}$ & N/A & $\begin{array}{l}\text { Fr juice is } \\
\text { used to cure } \\
\text { cold. }\end{array}$ & & $\mathrm{Fr}=$ winter \\
\hline $\begin{array}{l}\text { Murraya } \\
\text { koenigiil Curry } \\
\text { Leaf/ Gandhelu }\end{array}$ & $\begin{array}{l}\text { Samba } \\
\text { r, Veg } \\
\text { curry, } \\
\text { Chutn } \\
\text { ey\& } \\
\text { Jam }\end{array}$ & Ts\&Fr & $\begin{array}{ll}1500 & \mathrm{~m} \\
(\mathrm{Sh}) & \end{array}$ & 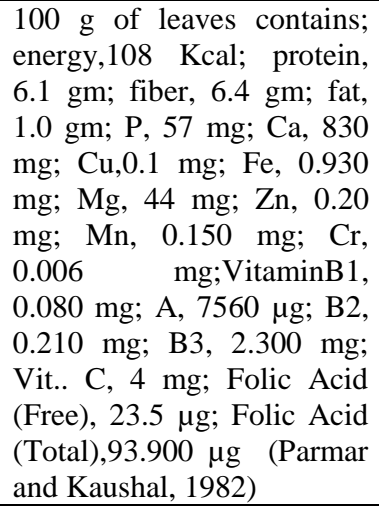 & $\begin{array}{l}\text { The } \mathrm{Lf}, \mathrm{Br} \& \\
\text { Rt are used as } \\
\text { a tonic \& } \\
\text { stomachic. }\end{array}$ & $\begin{array}{l}\text { LF are effective in treating } \\
\text { anxiety \& depression. The } \\
\mathrm{Br} \& \text { Rt are used as a } \\
\text { stimulant by the physicians. } \\
\text { Used externally to cure } \\
\text { eruptions \& the bites of } \\
\text { poisonous animals. } \\
\text { (Kritikar \& Basu, 1935) }\end{array}$ & $\begin{array}{l}\text { Leaves = } \\
100 \mathrm{~g} \text { earn } \\
30 \text { to } 50 \mathrm{Rs} \\
\text { for them }\end{array}$ \\
\hline $\begin{array}{l}\text { Zanthoxylum } \\
\text { armatum/ } \\
\text { Winged prickly } \\
\text { ash/ Tirmire }\end{array}$ & $\begin{array}{l}\text { Chutn } \\
\text { ey, } \\
\text { Patrod } \\
u \& \text { Sd } \\
\text { soup } \\
\end{array}$ & $\begin{array}{l}\text { Lf \& } \\
\text { Fr }\end{array}$ & $\begin{array}{l}2000 \quad \mathrm{~m} \\
(\mathrm{Sh})\end{array}$ & N/A & $\begin{array}{l}\text { St used as } \\
\text { toothbrush }\end{array}$ & $\begin{array}{l}\text { Fr, } \mathrm{Br} \& \mathrm{Sd} \text { are used as } \\
\text { antihelmintic, stomachic, } \\
\text { tonic \& in curing various } \\
\text { common ailments such as } \\
\text { toothache, common cold, }\end{array}$ & $\begin{array}{l}\text { Fr= } \\
\text { summers to } \\
\text { autumn } \\
\text { Le= } \\
\text { Throughout }\end{array}$ \\
\hline
\end{tabular}




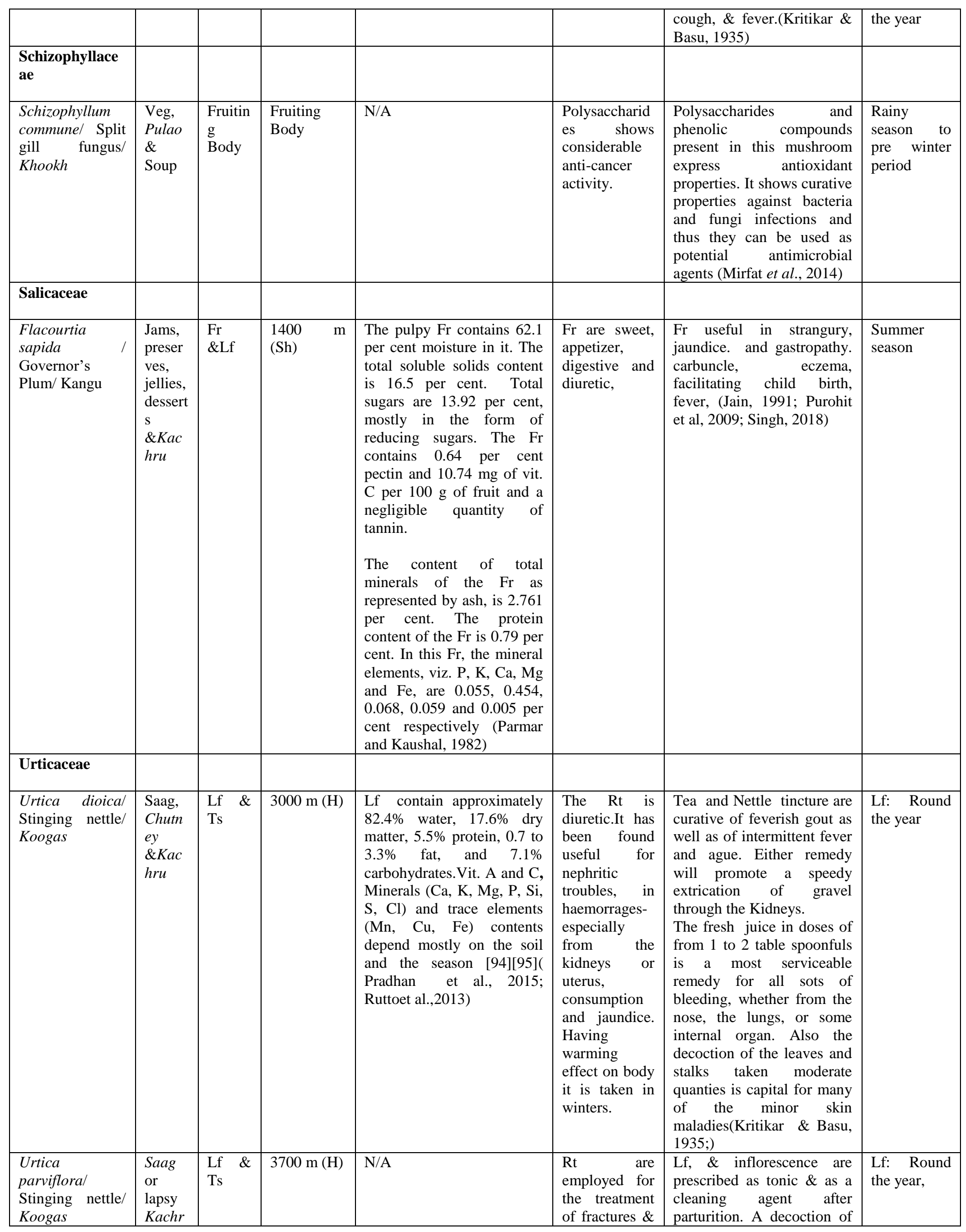




\begin{tabular}{|c|c|c|c|c|c|c|c|}
\hline & $\begin{array}{l}u \\
\text { Chutn } \\
\text { ey, } \\
\text { Tea }\end{array}$ & & & & dislocations. & $\begin{array}{l}\text { this herb is given in } \\
\text { fevers(Kritikar \& Basu, } \\
\text { 1935; Chopra, et al., 1956; } \\
\begin{array}{l}\text { Grieve,19841 } \\
\text { \&Ayensu; 1985.) }\end{array} \\
\end{array}$ & \\
\hline \multicolumn{8}{|l|}{ Violaceae } \\
\hline $\begin{array}{l}\text { Viola pilosal } \\
\text { Smooth-Leaf } \\
\text { White/ Banfsa }\end{array}$ & $\begin{array}{l}\text { Masal } \\
\text { a Tea } \\
\& K a c \\
h r u\end{array}$ & $\begin{array}{l}\text { Lf, Fl } \\
\text { buds } \\
\text { and } \mathrm{Fl}\end{array}$ & $\begin{array}{l}\text { 900- } 3000 \\
\mathrm{~m}(\mathrm{H})\end{array}$ & & $\begin{array}{l}\text { Decoction of } \\
\text { Lf,St \& Fl is } \\
\text { widely used } \\
\text { by rocal } \\
\text { people to } \\
\text { cures cough, } \\
\text { cold, chest } \\
\text { infection. and } \\
\text { lung diseases. }\end{array}$ & $\begin{array}{l}\text { Decoction of Rt is good for } \\
\text { vaginal discharge. Recorded } \\
\text { in India as an antipyretic, } \\
\text { diaphoretic, demulcent, } \\
\text { emetic, emollient, febrifuge } \\
\text { and purgative, and for } \\
\text { biliousness, (Sood \& } \\
\text { Thakur, 2004; Purohit et al., } \\
\text { 2009; Singh, 2018) }\end{array}$ & $\begin{array}{l}\text { Fr from pre } \\
\text { spring to } \\
\text { mid } \\
\text { summer/ } \\
\text { dried Fl Rs } \\
25,000 / \mathrm{kg}\end{array}$ \\
\hline \multicolumn{8}{|l|}{ Zingiberaceae } \\
\hline $\begin{array}{l}\text { Curcuma } \\
\text { aromatic /Wild } \\
\text { Turmeric/Van } \\
\text { haldi }\end{array}$ & $\begin{array}{l}\text { Halwa } \\
\& \\
\text { Haldi }\end{array}$ & $\mathrm{Rh}$ & $1000 \mathrm{~m}(\mathrm{H})$ & N/A & $\begin{array}{l}\mathrm{Rh} \text { are bitter, } \\
\text { carminative, } \\
\text { appetizer and } \\
\text { tonic. }\end{array}$ & $\begin{array}{l}\text { The plant contain strong } \\
\text { antibiotic properties. These } \\
\text { are used in combination } \\
\text { with astringent and } \\
\text { aromatics for bruises, } \\
\text { sprains, and hiccough, } \\
\text { bronchitis, } \\
\text { leukoderma, skin eruptions } \\
\text { snakebite and antibiotic } \\
\text { (Bown, 1995; Chopra, et al., } \\
\text { 1956;Purohit et al., } \\
\text { 2009; } \text { http://www.flowersofi } \\
\text { ndia.net/; Devi et al., 2014.) }\end{array}$ & $\begin{array}{l}\text { Summer end } \\
\text { to spring } \\
\text { season / }\end{array}$ \\
\hline $\begin{array}{l}\text { Hedychium } \\
\text { coronarium/ } \\
\text { Butterfly } \\
\text { Ginger/ Safed - } \\
\text { Banadark }\end{array}$ & $\begin{array}{l}\text { Kachr } \\
\text { u, } \\
\text { Pakor } \\
\text { as, } \\
\text { Pakor } \\
\text { a } \\
\text { curry, } \\
\text { Pickle } \\
\text { \&Ray } \\
\text { ata }\end{array}$ & $\begin{array}{l}\mathrm{Fl} \\
\text { buds } \\
\& \mathrm{Fl}\end{array}$ & $2500 \mathrm{~m}(\mathrm{H})$ & N/A & $\begin{array}{l}\text { The ground } \\
\text { Rh is used to } \\
\text { cure fever. }\end{array}$ & $\begin{array}{l}\text { Anti-cancerous, antioxidant, } \\
\text { anti-microbial, anti-fungal, } \\
\text { antihypertensive etc } \\
\text { Essential oil from rhizomes } \\
\text { is used in the treatment of } \\
\text { body aches, cold, contusion, } \\
\text { diabetes, headache, } \\
\text { inflammation,(Duke \& } \\
\text { Ayensu, 1985; Endringera } \\
\text { et al., 2014) }\end{array}$ & $\begin{array}{l}\mathrm{Fl}= \\
\text { Autumn } \\
\text { winters }\end{array}$ \\
\hline $\begin{array}{l}\text { Hedychium } \\
\text { spicatum / } \\
\text { Kapoor Kachri/ } \\
\text { Shoyee }\end{array}$ & $\begin{array}{l}\text { Kachr } \\
u \quad \text { or } \\
\text { sosaru } \\
\text { Pickle } \\
\& \\
\text { Masal } \\
\text { a tea }\end{array}$ & $\begin{array}{l}\text { Rh. Fl } \\
\&, F l \\
\text { buds }\end{array}$ & $\begin{array}{l}1200-3000 \\
\mathrm{~m}(\mathrm{H})\end{array}$ & N/A & $\begin{array}{l}\text { Powered } \\
\text { rootstock is } \\
\text { expectorant, } \\
\text { febrifuge and } \\
\text { tonic, }\end{array}$ & $\begin{array}{l}\text { Ayurveda it is used against } \\
\text { bowl complaints, vomiting, } \\
\text { fever, diarrhea, bronchitis } \\
\text { and rheumatic swellings. } \\
\text { Cure nausea, bronchial } \\
\text { asthma. diminished } \\
\text { appetite, hiccups.(Bown, } \\
\text { 1995;Sood and Thakur, } \\
\text { 2004; Purohit et al., } \\
\text { 2009;Singh, 2018.) }\end{array}$ & $\begin{array}{l}\text { Pre- winter } \\
\text { to spring } \\
\text { season }\end{array}$ \\
\hline
\end{tabular}

Abbrevation: $\mathrm{Fl}=$ Flower, Le= Leaves, $\mathrm{Bu}=\mathrm{Bulb}, \mathrm{Bl}=$ Bulbils, $\mathrm{Sd}=\mathrm{Seeds}, \mathrm{Ts}=\mathrm{Tender}$ shoot, $\mathrm{St}=\mathrm{Stem}, \mathrm{Lf}=\mathrm{Leaf}$, $\mathrm{Rt}=$ Root, Bd= Bulb, Tu= Tuber, $\mathrm{Po}=$ Pods, Rh= Rhozome, $\mathrm{Hb}=$ Herb, Sh= Shrub, T= Tree.Vit.=Vitamin.

\section{To know about the medicinal and nutritive value of wild food plants useful in boosting immunity, fight COVID-19 and future challenges like COVID-19.}

Ninety five plants documented in this study are either rich in antioxidants, used as tonic or are medicinally rich to cure cold, cough, fever and bronchitis symptoms similar to 
COVID-19. These plants are important ingredients of many traditional and modern medicine, which are used to cure a variety of ailments from time immortal. Almost comparable findings were reported by other workers. (Dutt, 2013; Sharma, et al., 2017; Patil\& Kakde, 2020) and Babich, et al., 2020).

Some of these wild food plants like Achyranthes aspera, Berberis lyceum, Euphorbia hirta, Kalanchoe pinnata, Centella asiatica, Moringa oleifera, Taraxacum officinale, Oxalis sp, Indigofera spp., Rumex spp, and Tinospora cordifolia are usually eaten as a food supplement to harness their rich medicinal and food values in spite of their unpleasant taste. Plants like Urtica spp., Galium aparin, Fagopyrum spp.Phyllanthus emblica, Angelica glauca, Terminalia spp. Origanum vulgare, Cinnamomum tamala, Ficus racemosa, Oxalix spp. Citrus spp, Asparagus spp.Kalanchoe pinnata, Hedychium spp. Phytolacca acinosa and Curcuma aromaticetc. are known for their rich nutritive value and are excellent source of antioxidants like Vitamin A, C and minerals like $\mathrm{Zn}, \mathrm{Mg}$, Mn etc. so are traditionally used to boost immunity and treat wide range of aliment along with bronchitis, fever, cold \& cough (Fig.5 \&Table.2).

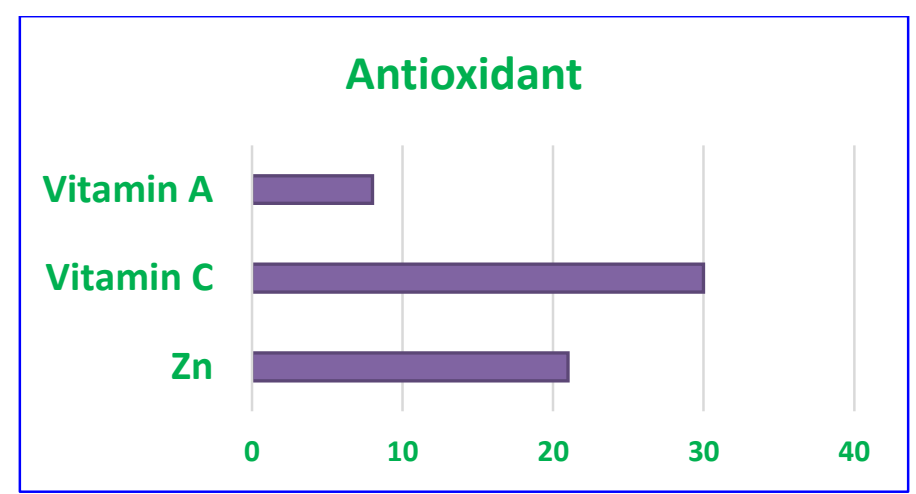

Fig. 4.Diversity of wild food plants rich in antioxident and helpful to boost immunity.

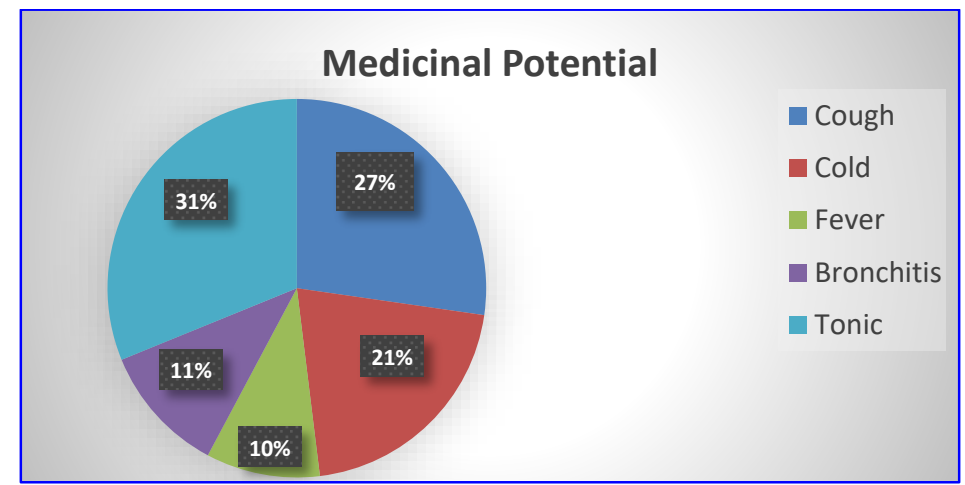

Fig. 5. Medicinal potential of wild food plants to fight and avoid COVID -19 symptom.

3. To know the traditional method of involving these plants in our day-to-day life and latest methods of their use as a food and food supplement with a modern twist. 
Many food plants like Dioscorea spp, Ficus spp. Morchella esculenta and Fagopyrum spp. are known as seasonal delicacies and eaten for their unique flavour or taste. Some of these like Ficus spp. Dioscorea spp and Morchella esculenta have their traditional recipes and a few like Ficus spp are usually prepared with some acidulent. These food items are liked by all. Therefore, they are in high demand and fetch high market prices in the local, national and international market. Wild food plants like Cirsium arvense and Urtica spp. appears poisonous and are harmful due to the presence of spines or pickers, so special care has to be taken during their harvesting and cooking. For many people these are non-edible and very few might know that these can be cooked into delicious dishes.

Wild food plants like Oxalis spp, Indigofera spp., Rumex spp, Rosa spp., Hedychium spicatum are excellent addition to pakoras, rayata, Kachru, chutney, masala oats and many other traditional dishes. Some of wild food plants like Angelica glauca, Allium ampeloprasum, Cinnamomum tamala, Cyclospermum leptophyllum, Origanum vulgare are used as spices and flavouring agents in various traditional dishes (Thakur, 2020). Addition of these nutritionally important medicinal wild food plants in tempting traditional food preparation like kachru, poha, soups, masala oats, kachuri, Potato fingers, kachuri, kheer, pakoras, bhale will be an excellent way to make kids of ruling era (who are generally very choosy for their meal) to eat what we want them to intake to boost their immunity and face ongoing challenges of pollution, stress, depression and pandemic like COVID-19 (Fig.6 \& Table.2).

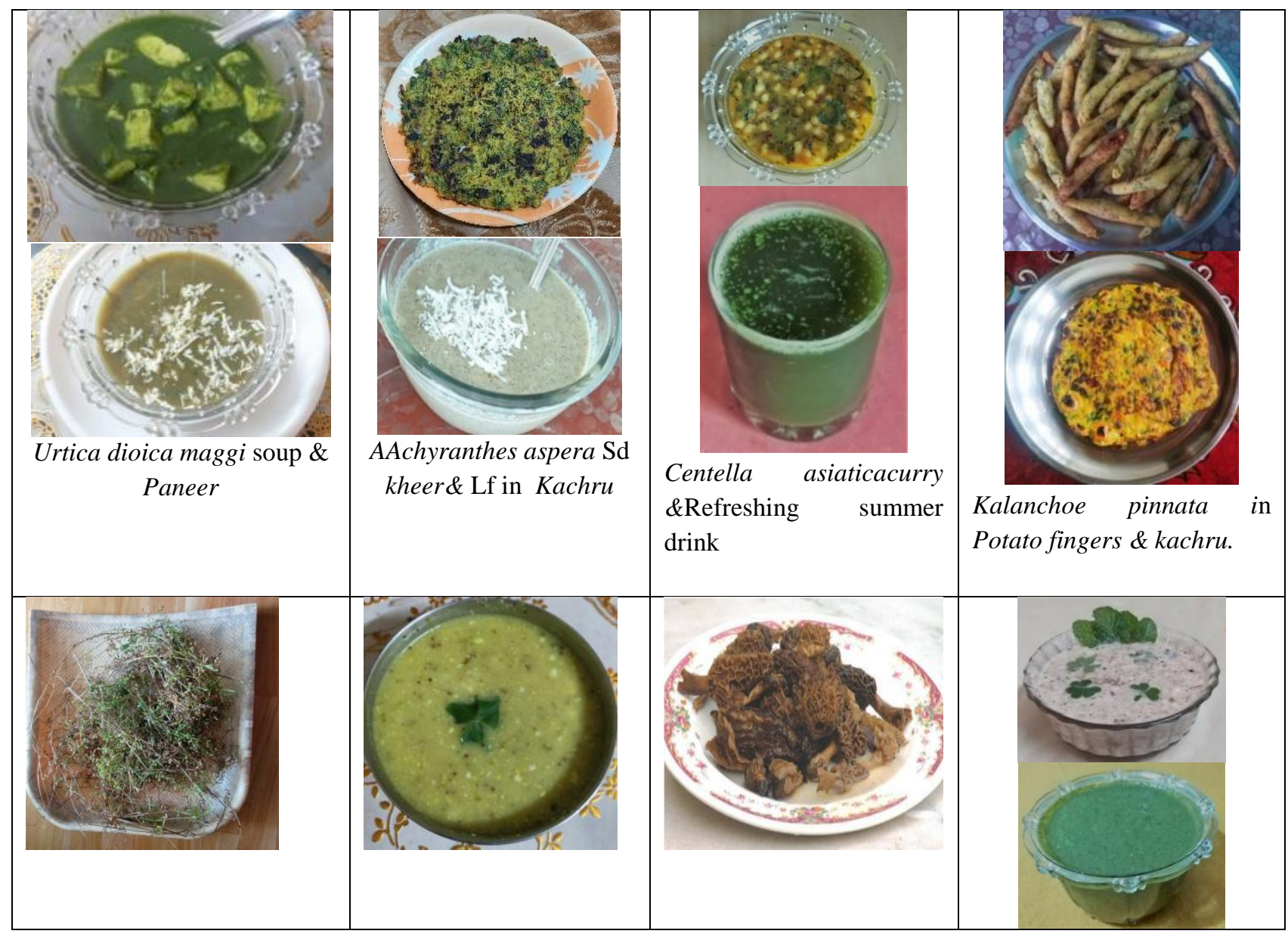




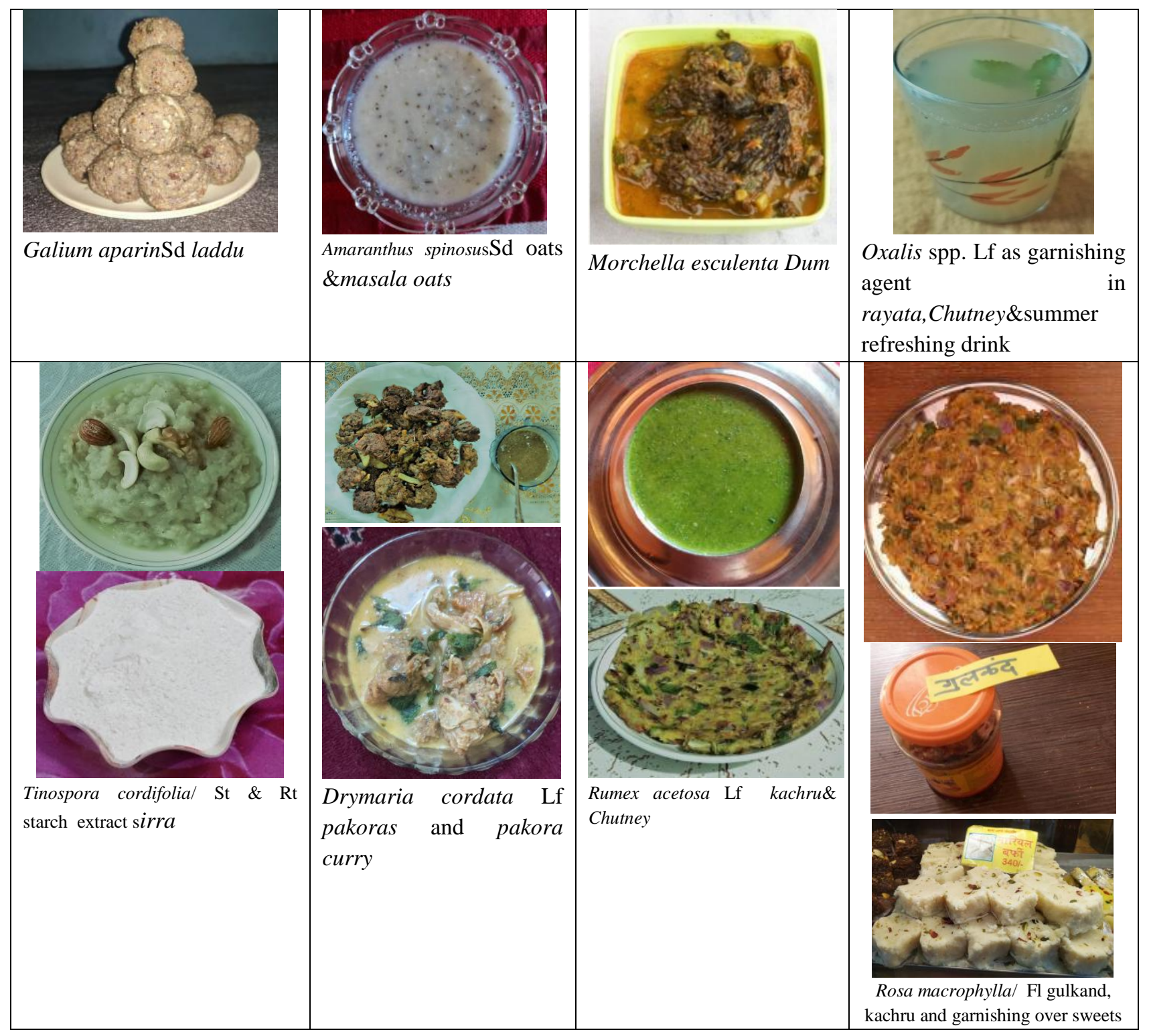




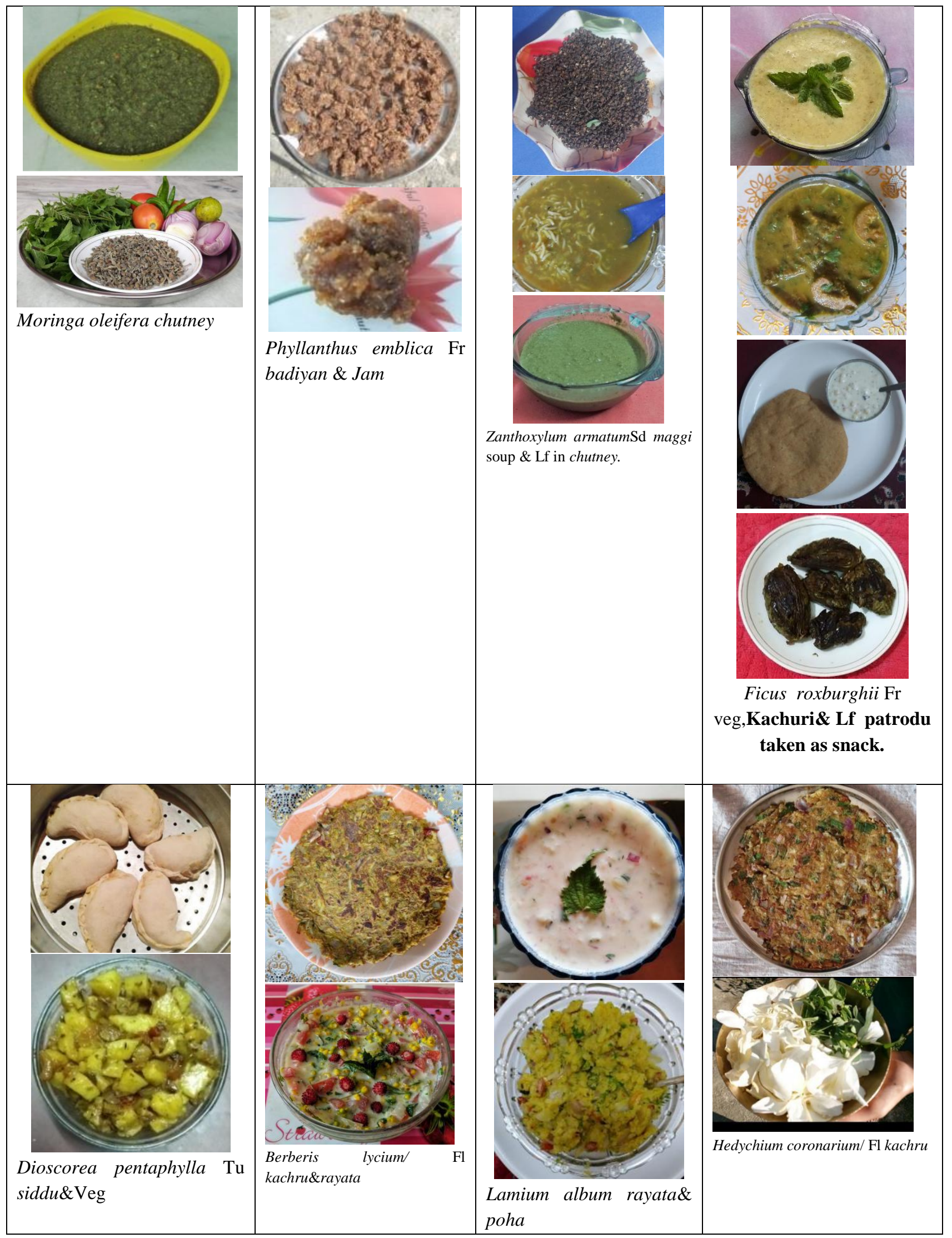

Copyright (C 2020-2021, Journal of Scientific Research in Medical and Biological Sciences (JSRMBS), Under the license CC BY- 4.0 


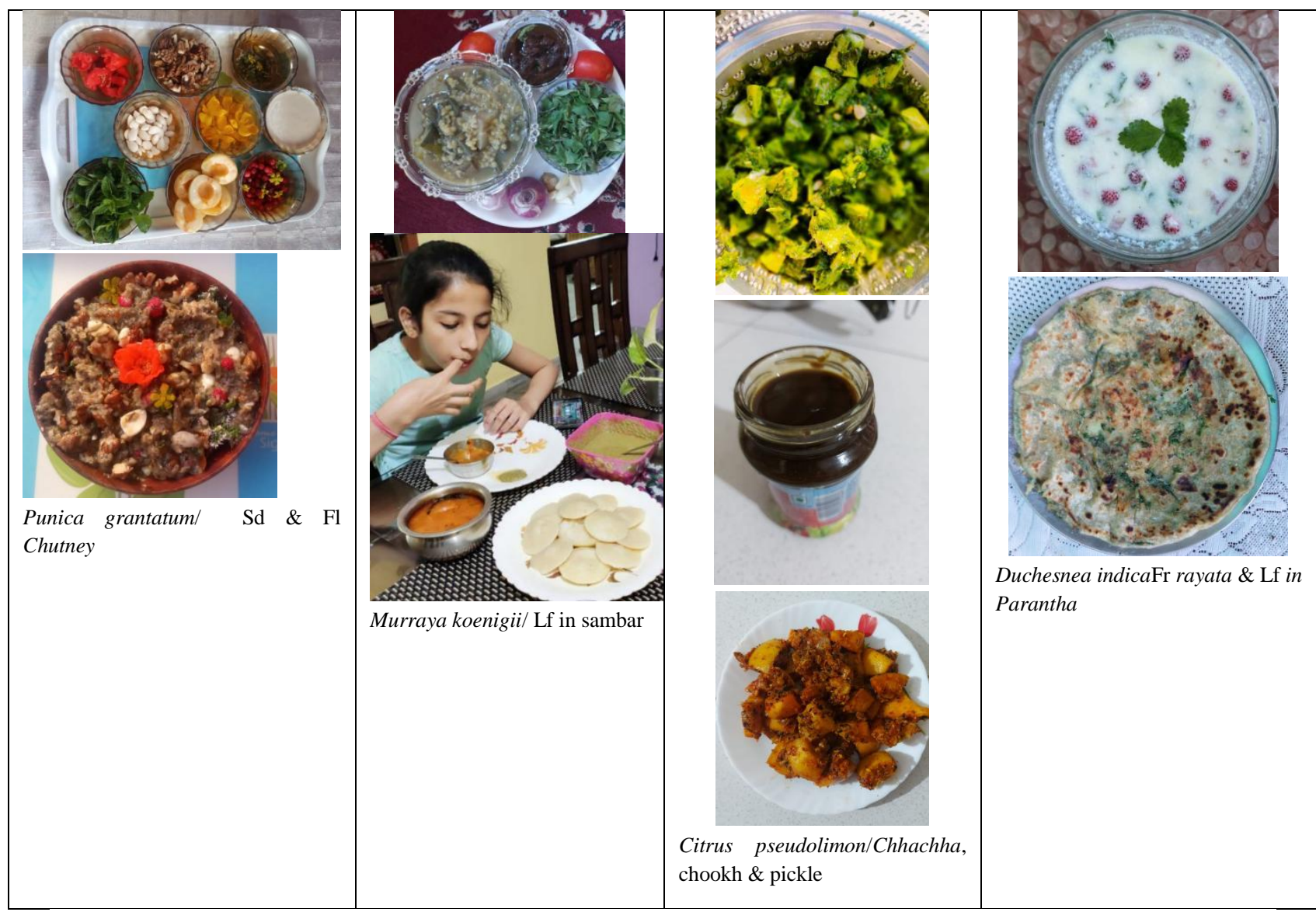

Fig. 6. Some traditional recipes with modern twist

Wild food plants like Achyranthes aspera, Amaranthus spinosus and Trifolium repens are considered emergency food and are eaten at the time of food scarcity. It is believed that kheer made from seeds of Achyranthes aspera (Puthkanda), if eaten one will not feel hungry for five days. Wild edible plants like Angelica glauca, Berberis lycium, Terminalia chebula, and Ziziphus mauritiana are used in the preparation of alcoholic drinks for local personal uses (Thakur, 2020).

Most of the herbaceous food plants are cooked as a leafy vegetable saag traditionally and local people used to prepare saag from more than seventy herbs. This is used to be a scientific practice of involving most of the medicinal herbs in small quantities to avoid their unpleasant taste and any adverse effect that might be due to their excessive use. But with the passage of time, this practice is losing ground and need to be revitalize (Fig.6 \& Table.2)..

\section{Conclusion and Suggestion}

Industrialization, urbanization and modernization for the last few decades has drastically changed our lifestyle, food habits and working schedule. As a result, we are not as resistant to diseases as our ancestors used to be. Therefore, there is a need to incorporate the medicinal plants presented in this study which are rich in Vitamin $\mathrm{A}, \mathrm{C}, \mathrm{Zn}, \mathrm{Mg}$ and other antioxidant into our day-to-day lives with some modern twist for boosting immunity. Traditional knowledge of using wild plants as a source of food, vegetable and medicine has 
declined in recent few years and is at the verge of extinction among young people who are more prone to adverse situations like COVID-19, pollution and other lifestyle diseases. Hence, it is important to document traditional knowledge related to wild edible medicinal plants which can be included with some modern twist in our food plate.The list of nutritionally important medicinal wild food plants that grow in the Western Himalayas andhelpful toensure food security, overcome hunger crisis and support the body during the pandemic is yet to be completed. As wild-growing food plants are free from chemical fertilizers, pesticides and insecticides and rich in medicinal and nutritive values, they can play an important role in boosting our immunity, fighting COVID-19, and other future challenges like COVID-19. They can also act also be useful in fighting other lifestyle diseases, such as depression, thyroid, obesity, diabetes, blood pressure, etc. Therefore, it is important to include all the important herbs in small quantity as a food supplement in recipes with some modern twist like meggi, poha, chilla, sandwitch, momoe's etc, which are highly favoured by young generation.By utilizing these plants we can make our present and future generation happy, healthy and strong. It is, therefore, recommended that wild food plants need to be involved in day-to-day life with some modern twist in recipes. There should be awareness among inhabitants for sustainable use and harvesting of wild food plants. It is also recommended to promote wild items recipes in hotels and restaurants run by the government and private entrepreneurs.

\section{Acknowledgements}

The author is highly indebted to the inhabitants of Himachal Pradesh for providing valuable information about wild food plants locally used as a tonic and helps to cure old.fever,cough and bronchitis Sincere thanks also go to Dr S.S. Samant, Dr. Chiranjit Parmar, Dr, Sanjeet Singh, Bhavana Bhardwaj, an official of district statistical department, botany department of Sardar VallabhbhaiCluster University Mandi for their encouragement, support and cooperation.The author is also highly thankful to DEST Himachal Pradesh for providing funds to carry on this research. 


\section{Conflict of Interest}

None

Funding:

DEST Himachal Pradesh

\section{References}

Abdel E. Ghaly et al. (2012). Nutrient Composition of Dandelions and its Potential as Human Food. American Journal of Biochemistry and Biotechnology. 8 (2), 118-127

Ambasta, S. S. (1986). The useful plants of India (p. 650). CSIR, New Delhi, India: Publications \& Information Directorate.

Anonymous, (1985). Wealth of India: Raw Materials, Vol I, CSIR., New Delhi.

Arayne, M. S., Sultana, N., Mirza, A. Z., Zuberi, M. H., \& Siddiqui, F. A. (2007). In vitro hypoglycemic activity of methanolic extract of some indigenous plants. Pak J Pharm Sci, 20(4), 268-273.

Asamenew, G., Tadesse, S., Asres, K., Mazumder, A., \& Bucar, F. (2008). A study on the composition, antimicrobial and antioxidant activities of the leaf essential oil of Apium leptophylum (Pers.) Benth. growing in Ethiopia. Ethiopian Pharmaceutical Journal, 26(2).

Babich, O., Sukhikh, S., Prosekov, A., Asyakina, L., \& Ivanova, S. (2020). Medicinal Plants to Strengthen Immunity during a Pandemic. Pharmaceuticals, 13(10), 313.

Badgujar, S. B., Patel, V. V., \& Bandivdekar, A. H. (2014). Foeniculum vulgare Mill: a review of its botany, phytochemistry, pharmacology, contemporary application, and toxicology. BioMed research international, 2014.

Barua, C. C., Bora, M., Saikia, B. N., Hazarika, M., Misri, J., \& Chandrabarua, I. (2015). Nutritional evaluation of few selected medicinal plants of north eastern region. Int. J. Pharm. Biosci, 6, 538-546..

Basumatary, S., \& Narzary, H. (2017). Nutritional value, phytochemicals and antioxidant property of six wild edible plants consumed by the Bodos of North-East India. Mediterranean Journal of Nutrition and Metabolism, 10(3), 259-271.

Bhalla, D. K., \& Owen, R. L. (1982); Cell renewal and migration in lymphoid follicles of Peyer's patches and cecum - an autoradiographic study in mice. Gastroenterology, 82(2), 232-242.

Bhat, J. A., Kumar, M., \& Bussmann, R. W. (2013): Ecological status and traditional knowledge of medicinal plants in Kedarnath Wildlife Sanctuary of Garhwal Himalaya, India. Journal of Ethnobiology and Ethnomedicine, 9(1), 1.

Bown. D.(1995): Encyclopaedia of Herbs and their Uses. Dorling Kindersley, London. ISBN 0-7513-020-31! 238

Burkill, H. M. (1995). The useful plants of west tropical Africa, Vols. 1-3. The useful plants of west tropical Africa, Vols. 1-3., (2. ed.). 
Buruleanu, L. C., Radulescu, C., Georgescu, A. A., Danet, F. A., Olteanu, R. L., Nicolescu, C. M., \& Dulama, I. D. (2018). Statistical characterization of the phytochemical characteristics of edible mushroom extracts. Analytical Letters, 51(7), 1039-1059.

Chatterjee, A., \& Pakrashi, S. C. (1997). The Treaties on Indian medicinal plants, volume-3. National Institute of Science Communication (CSIR), New Delhi, 16.

Chauhan, N. S. (1999). Medicinal and aromatic plants of Himachal Pradesh. Indus publishing.

Chiej. R. (1984). Encyclopaedia of Medicinal Plants. ISBN;0-356-10541-5.

Chopra. R. N., Nayar. S. L. and Chopra. I. C (1982): Glossary of Indian Medicinal Plants. Council of Scientific and Industrial Research, New Delhi.

Chowdhary, H. J., \& Wadhwa, B. M. (1984): Flora of Himachal Pradesh Analysis. Vol. I. Botanical Survey of India, Calcutta.

Collett, H. (1902): Flora Simlensis. Thacker Spink \& Co Calcutta and Simla, Reprinted 1971. Bishen Singh Mahendra Pal Singh, Dehradun.

Dahot MU. (1988); Vitamin contents of flowers and seeds of Moringa oleifera. Pak J Biochem 21: 1-24Lam. Bulletin of Medico-Ethno-Botanical Research 17: 141-151.

Devi T, Sen V. (2020): "Role of Wild Food Plants in Culinary Tourism Development of District Mandi Himachal Pradesh," International Journal of Scientific Research in Biological Sciences, Vol.7, Issue.6, pp.14-38.

Devi, N. B., Singh, P. K., \& Das, A. K. (2014). Ethnomedicinal utilization of Zingiberaceae in the valley districts of Manipur. J. Environ. Sci. Toxicol. Food Technol, 8(2), 21-23.

Devi, T. (2020). Traditional use and role of wild edible fern Diplazium esculentum and Pteridium aquilinum in socio-economic development of District Mandi of Himachal Pradesh, North Western Himalaya, International Journal of Scientific Research in Biological Sciences, Vol.7, Issue.6, pp.44-50, 2020.

Dhaliwal, D.S. \& Sharma, M,(1999): Flora of Kullu District (Himachal Pradesh) Bishen Singh Mahendra Pal Singh, Dehradun.

Dhiman, D. R. (1976). Himachal Pradesh Ki Vanoshdhiya Sampada.

Duke JA, Ayensu ES.(1985) Medicinal plants of China. Reference Publications.

Dury, G. H. (1978). The future of geomorphology. na.

Dutt, S. B. (2013). PA02. 10. A review on immunomodulator activity of some indiginious medical plants. Ancient Science of Life, 32(Suppl 2), S55.

Endringera DC, Taveira FSN, Kondratyuk TP, Pezzuto JM and Braga FC (2014). Cancer chemoprevention activity of labdane diterpenes from rhizomes of Hedychium coronarium. Rev. Bras. Farmacogn., 24(4);4. 08-412

Fernandes, Â., Oliveira, M. B. P., Martins, A., \& Ferreira, I. C. (2012). Add-value of Lactarius deliciosus and Macrolepiota procera wild mushrooms due to their nutritional and nutraceutical potential. In International Congress on Pormotion of Traditional Food Products, 3 a 5 de Maio de 2012

Flyman, M.V. and Anthony, J.A. (2007). Proximate and mineral composition of the leaves of Momordica balsamina L.: an underutilized wild vegetable in Botswana. Int. J. Food Sci. Nutr., 58(6), 419-423.

Gamble. J. S. (1972). A Manual of Indian Timbers. Bishen Singh Mahendra Pal Singh. 
Gills, L.S. (1992) Ethnomedical Uses of Plants in Nigeria. Uniben Press: Edo State Nigeria, p. 12

Gills, L.S. (1992). Ethnomedical Uses of Plants in Nigeria. Uniben Press: Edo State Nigeria,

Grieve, M. (1984). Tansy. A Modern Herbal. Penguin Books Ltd, Middlesex, Great Britain, 789-790.

Gulfraz M, Arshad M, Nayyer N, Kanwal N, Nisar U (2004). Investigation for bioactive compounds of Berberis lyceum Royle and Justicia adhatoda L. Ethnobot. Leaflets 1:51-62.

Hardel DK, Das AK, Bhanja S. (2012). A comparison study of fluorescence characteristics of powder of Haritaki: Terminalia chebula (pericarp), Yavani: Trachyspermum ammi (fruit), Ajmoda: Apium leptophyllum (fruit), Sunthi: Zingiber officinale (rhizome) Int Res J Pharm, 3:255-7.

Hassan, L.G. and Umar, K.J. (2006). Nutritional value of balsam apple (Momordica balsamina L.) leaves. Pak. J. Nut., 5(6), 522- 529.

Holtom. J. and Hylton. W. (1979). Complete Guide to Herbs. Rodale Press Publication. ISBN; 0-87857-262-7.

Jain, S. K. (1991). Dictionary of Indian folk medicine and ethnobotany. Deep publications.

Joseph B, Raj SJ (2010). Phytopharmacological and phytochemical properties of three ficus species-an overview. Int J Pharma Bio Sci ;1:246-53.

Joseph, B., \& Raj, S. J. (2010). Phytopharmacological and phytochemical properties of three Ficus species-an overview. Int J Pharma Bio Sci, 1(4), 246-253.

Kamble, N. A., \& Velhal, V. V. (2010). Study of sodium fluoride toxicity on hematological parameter of Rattus norvegicus. In Biol Forum. 2(2), 56-8.

Kamboj, A., \& Saluja, A. (2009). Bryophyllum pinnatum (Lam.) Kurz.: phytochemical and pharmacological profile: a review. Pharmacognosy Reviews, 3(6), 364

Kapoor. L. D. (2001). Handbook of Ayurvedic Medicinal Plants.CRC Press, Florida.

Kar, A., Choudhary, B. K., \& Bandyopadhyay, N. G. (2003). Comparative evaluation of hypoglycaemic activity of some Indian medicinal plants in alloxan diabetic rats. Journal of ethnopharmacology, 84(1), 105-108.

Karnick, C. R., Tiwari, K. C., Majumdar, R., \& Bhattacharjee, S. (1981). Newer ethnobotanical and folklore studies of some medicinal plants of Gauhati and surrounding areas. Nagarjun, 24(11), 240-245.

Karthikumar, S., Vigneswari, K., \& Jegatheesan, K. (2007). Screening of antibacterial and antioxidant activities of leaves of Eclipta prostrata (L). Sci. Res. Essay, 2(4), 101-104.

Karuppusamy, S., Muthuraja, G., \& Rajasekaran, K. M. (2011). Antioxidant activity of selected lesser known edible fruits from Western Ghats of India. Indian Journal of Natural Produts and Resources. 2(2), 174-178.

Kermath, B. M., Bennett, B. C., \& Pulsipher, L. M. (2014). Food Plants in the Americas: A Survey of the Domesticated, Cultivated, and Wild Plants Used for Human Food in North, Central and South America and the Caribbean, Unpubl. Manuscript, Univ. Wisconsin Oshkosh, Oshkosh.

Kirtikar K.R. and B.D. Basu, (1935), Indian Medicinal Plants, Vols. I, II III and IV, Bishan Singh Mahendra Pal Singh, Dehradun.

Komor, P. \& Devi, O.S. (2016). Edible bioresources \& livelihoods. Assam State Biodiversity 
Board, Guwahat.

Kumar, S., Das, G., Shin, H. S., \& Patra, J. K. (2017). Dioscorea spp.(a wild edible tuber): a study on its ethnopharmacological potential and traditional use by the local people of Similipal Biosphere Reserve, India. Frontiers in pharmacology, 8, 52.

Kundan, P. (2014). Evaluation of antioxidant, vitamins, phytochemicals and nutritive values of Euphorbia hirta Linn. Research Journal of Phytochemistry, 8(2), 47-51.

Landy, D. (1977). Culture, disease and healing. Studies in medical anthropology, 467.

Launert. E. (1981). Edible and Medicinal Plants.

Manandhar. N. P.(2002). Plants and People of Nepal. Publication; Timber Press. Oregon.ISBN; 0-88192-527-6

Mirfat A. H. S., Noorlidah, A., \& Vikineswary, S. (2014). Antimicrobial activities of split gill mushroom Schizophyllum commune Fr. American Journal of Research Communication, 2(7), 113-124.

Moerman, D. E. (1998). Native American Ethnobotany. Timber press.

Nayar, S. L., Chopra, I. C., \& Chopra, I. C. (1956). Glossary of Indian Medicinal Plants New Delhi.

Nitha, B., Meera, C. R., \& Janardhanan, K. K. (2007). Anti-inflammatory and antitumour activities of cultured mycelium of morel mushroom, Morchella esculenta. Current Science, 235-239.

Nwali, B. U., Okaka, A. N. C., Offor, C. E., Aja, P. M., \& Nwachi, U. E. (2014). Proximate and Mineral Compositions of Bryophyllum pinnatum Leaves. American Journal of Phytomedicine and Clinical Therapeutics. 2(3), 286-289.

Otimenyin, O.S.; Uguru, O.M. and Ogbonna, A. (2008) Antimicrobial and hypoglycemic effects of Momordica balsamina. Linn.. J. Nat. Prod., 1, 03-09.

Kar, P., Dey, P., Misra, A. K., Chaudhuri, T. K., \& Sen, A. (2016). Phytometabolomic fingerprinting of selected actinorhizal fruits popularly consumed in North-East India. Symbiosis, 70(1), 159-168.

Parmar. C. and Kaushal. M.K. (1982). Wild Fruits of the Sub-Himalayan Region. Kalyani Publishers. New Delhi.

Patel, A. V., Rojas-Vera, J., \& Dacke, C. G. (2004). Therapeutic constituents and actions of Rubus species. Current medicinal chemistry, 11(11), 1501-1512.

Patil, A., \& Kakde, M. (2020). Medicinal plant as a natural immunity booster for COVID19A review. Indian Journal of Integrative Medicine, 24-27.

Pradhan S, Manivannan S, Tamang JP(2015). Proximate, mineral composition and antioxidant properties of some wild leafy vegetables. J Sci Ind Res. (74)155-9.

Prajapati, N. D., Purohit, S. S., Sharma, A. K., \& Kumar, T. (2003). A handbook of medicinal plants: A complete source book. In A handbook of medicinal plants: a complete source book (pp. 554-554).

Rani, S., Rana, J. C., \& Rana, P. K. (2013). Ethnomedicinal plants of Chamba district, Himachal Pradesh, India. Journal of Medicinal Plants Research, 7(42), 3147-3157.

Rutto LK, Xu Y, Ramirez E, Brandt M (2013). Mineral properties and dietary value of raw and processed stinging nettle (Urtica dioica L.). International journal of food science. (13), 1-9.

Sahoo, H. B., Patro, S. K., Sagar, R., \& Santani, D. D. (2015). Mutagenic evaluation and 
spectroscopic characterization of flavonoidal fraction of Apium leptophyllum (Pers.) fruit. International Journal of Nutrition, Pharmacology, Neurological Diseases, 5(2), 82.

Sajid, S. M., Zubair, M., Waqas, M., Nawaz, M., \& Ahmad, Z. (2015). A review on quince (Cydonia oblonga): a useful medicinal plant. Global Vetenaria, 14, 517-524.

Samant, S. S. \& Dhar, U. (1997): Diversity, endemism and economic potential of wild edible plants of Indian Himalaya. International Journal of Sustainable Development and World Ecology. (4) 179-191.

Santhi Sri, K. V., Rajamani, S. and Simhadri, S (2017). Amla, a Marvelous Fruit for Type -2 Diabetics-A Review. International Journal of Current Microbiology and Applied Sciences (5),116-123.

Scriber, J. Mark (1 January 1978). "Cyanogenic Glycosides in Lotus corniculatus. Their Effect upon Growth, Energy Budget, and Nitrogen Utilization of the Southern Armyworm, Spodoptera eridania". Oecologia. 34 (2), 143-155.

Sharma, P., Kumar, P., Sharma, R., Gupta, G., \& Chaudhary, A. (2017). Immunomodulators: Role of medicinal plants in immune system. National Journal of Physiology, Pharmacy and Pharmacology, 7(6), 552.

Shiksharthi, A. R., \& Mittal, S. (2011). Ficus racemosa: phytochemistry, traditional uses and pharmacological properties: a review. International Journal of Recent Advances in Pharmaceutical Research, 4, 6-15.

Mir, S. R., Ali, M., \& Kapoor, R. (2004). Chemical composition of essential oil of Cinnamomum tamala Nees et Eberm. leaves. Flavour and fragrance journal, 19(2), 112-114.

Singh, P.B. (1918). Flora of the Mandi District Himachal Pradesh North West Himalaya. Bishen Singh Mahendra Pal Singh, Dehradun. ISBN: 9788121109628.

Sood SK, Thakur S. (2004). Ethnobotany of Rewalsar Himalaya. Deep Publications.

Thakur, ST. (2021). An Illustrated Guide To Some Wild growing Food Plants of The Sub Himalayan Region. Narayan Publication.

Tsarong. Tsewang. J. (1994). Tibetan Medicinal Plants.Tibetan Medical Publications, India; ISBN; 81-900489-0-2

Uniyal, S. K., Singh, K. N., Jamwal, P., \& Lal, B. (2006). Traditional use of medicinal plants among the tribal communities of Chhota Bhangal, Western Himalaya. Journal of ethnobiology and ethnomedicine, 2(1), 1-8.

Uniyal, M. R. (1968). Medicinal plants of Bhagirathi valley lying in Uttarkashi forest division. Indian Forester, 94, 407-420.

Uphof. J. C. Th (1959). Dictionary of Economic Plants. Weinheim, publication.

Usher, G. (1974). A Dictionary of Plants Used By Man. Constable and Company Ltd

Watt, J.M. and Breyer-Brandwijk, M.G. (1962) Medicinal and Poisonous Plants of Southern and Eastern Africa. E\&S. Livingstone, Ltd., London.

Yeung, H. C. (2004). Handbook of Chinese Herbs and Formulas Institute of Chinese Medicine, Los Angeles. The American Soc Nutr Sci J Nutr, 134, 1105-59. 